Prepared in cooperation with the City of Boise, Idaho

Mercury Concentrations in Water and Mercury and Selenium Concentrations in Fish from Brownlee Reservoir and Selected Sites in the Boise and Snake Rivers, Idaho and Oregon, 2013-15

Open-File Report 2016-1098 



\section{Mercury Concentrations in Water and Mercury and Selenium Concentrations in Fish from Brownlee Reservoir and Selected Sites in the Boise and Snake Rivers, Idaho and Oregon, 2013-15}

By Marshall L. Williams and Dorene E. MacCoy

Prepared in cooperation with the City of Boise, Idaho

Open-File Report 2016-1098 


\section{U.S. Department of the Interior \\ SALLY JEWELL, Secretary}

\section{U.S. Geological Survey \\ Suzette M. Kimball, Director}

U.S. Geological Survey, Reston, Virginia: 2016

For more information on the USGS-the Federal source for science about the Earth,

its natural and living resources, natural hazards, and the environment-visit

http://www.usgs.gov or call 1-888-ASK-USGS

For an overview of USGS information products, including maps, imagery, and publications, visit http://store.usgs.gov/

Any use of trade, firm, or product names is for descriptive purposes only and does not imply endorsement by the U.S. Government.

Although this information product, for the most part, is in the public domain, it also may contain copyrighted materials as noted in the text. Permission to reproduce copyrighted items must be secured from the copyright owner.

Suggested citation:

Williams, M.L., and MacCoy, D.E., 2016, Mercury concentrations in water and mercury and selenium concentrations in fish from Brownlee Reservoir and selected sites in the Boise and Snake Rivers, Idaho and Oregon, 2013-15: U.S. Geological Survey Open-File Report 2016-1098, 29 p., http://dx.doi.org/10.3133/ofr20161098.

ISSN 2331-1258 (online) 


\section{Contents}

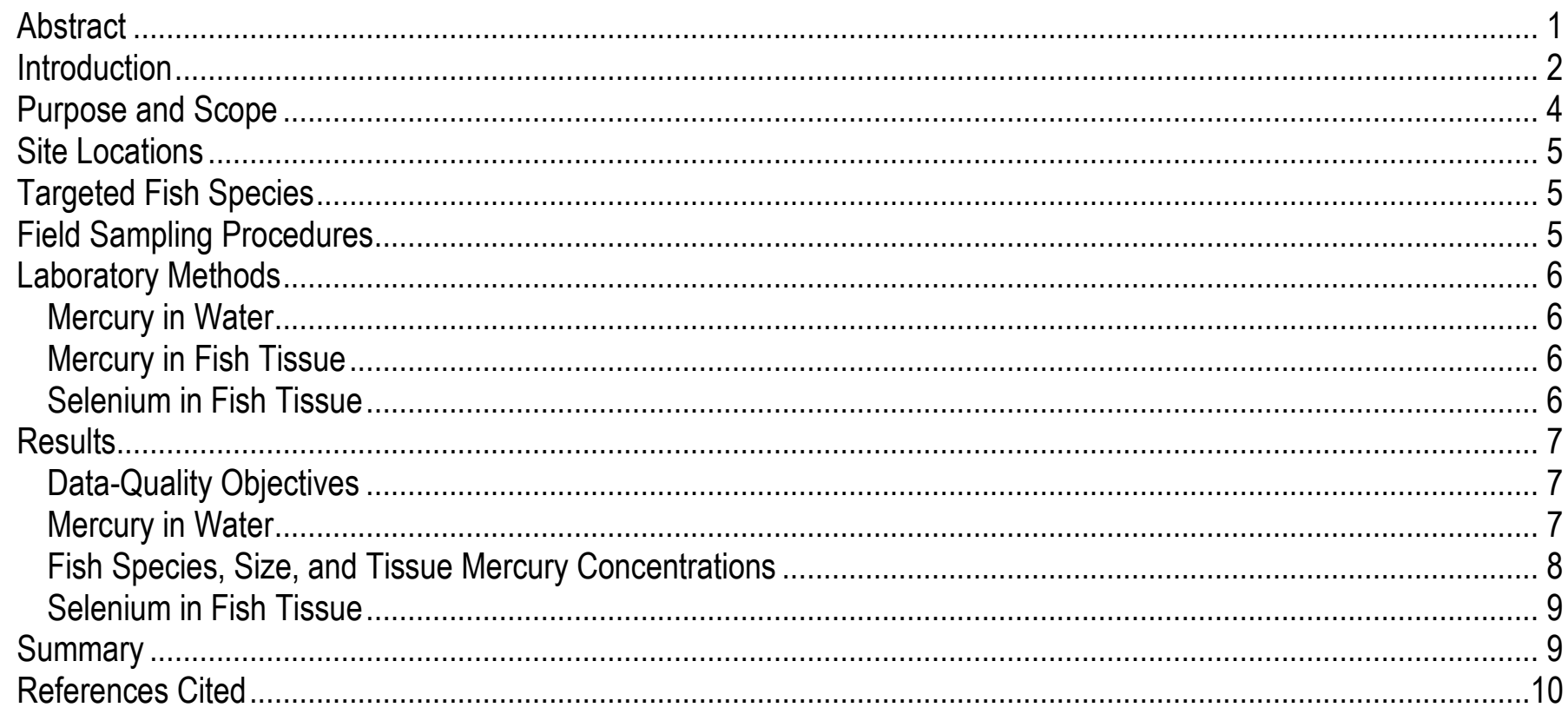

\section{Figures}

Figure 1. Map showing location of sites where water and fish tissue samples were collected for analysis of total mercury and selenium, Idaho and Oregon, 2013-15.

Figure 2. Photographs of channel catfish (a) and smallmouth bass (b) at the Snake River near Murphy sampling site, October 2013

Figure 3. Boxplot showing total mercury concentrations in fish tissue collected from sites in the Boise and Snake Rivers and Brownlee Reservoir, October 2013-15, Idaho and Oregon

Figure 4. Graphs showing total mercury tissue concentrations and total length of mountain whitefish $(A)$, smallmouth bass $(B)$, channel catfish $(C)$, and rainbow trout $(D)$, in samples from the Boise and Snake Rivers and Brownlee Reservoir, Idaho and Oregon, 2013-15. 


\section{Tables}

Table 1. Sites in the Boise and Snake Rivers and Brownlee Reservoir where water and fish samples were collected for mercury analysis, Idaho and Oregon, 2013-15

Table 2. Targeted fish species in the Boise and Snake Rivers and Brownlee Reservoir, Idaho and Oregon

Table 3. Quality-control sample results for analysis of total mercury in fish from the Boise and Snake Rivers and Brownlee Reservoir, Idaho and Oregon, October 2013-15.

Table 4. Total mercury concentrations in water from the Boise and Snake Rivers and Brownlee Reservoir and associated field blanks and laboratory matrix spike recovery for samples collected in October and November, 2013-15.

Table 5. Individual sport fish tissue total mercury concentrations, fish size data, and statistical site summaries in samples collected from the Boise and Snake Rivers and Brownlee Reservoir, Idaho and Oregon, October 2013-15.

Table 6. Selenium concentrations in individual sport fish tissue collected from the Boise and Snake Rivers and Brownlee Reservoir, Idaho and Oregon, October 2013-15.

\section{Conversion Factors}

SI to Inch/Pound

\begin{tabular}{|c|c|c|}
\hline Multiply & By & To obtain \\
\hline \multicolumn{3}{|c|}{ Length } \\
\hline centimeter $(\mathrm{cm})$ & 0.3937 & inch (in.) \\
\hline millimeter $(\mathrm{mm})$ & 0.03937 & inch (in.) \\
\hline \multicolumn{3}{|c|}{ Volume } \\
\hline milliliter (mL) & 0.03381 & ounce, fluid (fl. oz) \\
\hline \multicolumn{3}{|c|}{ Mass } \\
\hline $\operatorname{gram}(\mathrm{g})$ & 0.03527 & ounce, avoirdupois (oz) \\
\hline kilogram (kg) & 2.205 & pound avoirdupois (lb) \\
\hline milligram (mg) & 0.000035 & ounce, avoirdupois (oz) \\
\hline nanogram (ng) & $3.5 \times 10^{-11}$ & ounce, avoirdupois (oz) \\
\hline
\end{tabular}

Concentrations of chemical constituents in water are given in micrograms per liter $(\mu \mathrm{g} / \mathrm{L})$, equivalent to part per billion; nanograms per liter (ng/L), equivalent to part per trillion; nanograms per gram (ng/g), equivalent to part per billion; and milligrams per kilogram (mg/kg), equivalent to part per million.

\section{Datum}

Horizontal coordinate information is referenced to the North American Datum of 1983 (NAD 83). 


\title{
Mercury Concentrations in Water and Mercury and Selenium Concentrations in Fish from Brownlee Reservoir and Selected Sites in the Boise and Snake Rivers, Idaho and Oregon, 2013-15
}

By Marshall L. Williams and Dorene E. MacCoy

\begin{abstract}
Mercury $(\mathrm{Hg})$ analyses were conducted on samples of sport fish and water collected from selected sampling sites in Brownlee Reservoir and the Boise and Snake Rivers to meet National Pollution Discharge and Elimination System (NPDES) permit requirements for the City of Boise, Idaho, between 2013 and 2015. City of Boise personnel collected water samples from six sites between October and November 2013 and 2015, with one site sampled in 2014. Total Hg concentrations in unfiltered water samples ranged from 0.48 to 8.8 nanograms per liter (ng/L), with the highest value in Brownlee Reservoir in 2013. All Hg concentrations in water samples were less than the U.S. Environmental Protection Agency (USEPA) Hg chronic aquatic life criterion of $12 \mathrm{ng} / \mathrm{L}$.

The USEPA recommended a water-quality criterion of 0.30 milligrams per kilogram $(\mathrm{mg} / \mathrm{kg})$ methylmercury ( $\mathrm{MeHg}$ ) expressed as a fish-tissue residue value (wet-weight $\mathrm{MeHg}$ in fish tissue). The Idaho Department of Environmental Quality adopted the USEPA's fish-tissue criterion and established a reasonable potential to exceed (RPTE) threshold 20 percent lower than the criterion or greater than 0.24 $\mathrm{mg} / \mathrm{kg} \mathrm{Hg}$ based on an average concentration of 10 fish from a receiving waterbody. NPDES permitted discharge to waters with fish having $\mathrm{Hg}$ concentrations exceeding $0.24 \mathrm{mg} / \mathrm{kg}$ are said to have a reasonable potential to exceed the water-quality criterion and thus are subject to additional permit obligations, such as requirements for increased monitoring and the development of a $\mathrm{Hg}$ minimization plan. The Idaho Fish Consumption Advisory Program (IFCAP) issues fish advisories to protect general and sensitive populations of fish consumers and has developed an action level of $0.22 \mathrm{mg} / \mathrm{kg} \mathrm{Hg}$ in fish tissue. Fish consumption advisories are water body- and species-specific and are used to advise allowable fish consumption from specific water bodies. The geometric mean $\mathrm{Hg}$ concentration of 10 fish of a single species collected from a single water body (lake or stream) in Idaho is compared to the action level to determine if a fish consumption advisory should be issued.
\end{abstract}


The U.S. Geological Survey collected and analyzed individual fillets of mountain whitefish (Prosopium williamsoni), rainbow trout (Oncorhynchus mykiss), smallmouth bass (Micropterus dolomieu), and channel catfish (Ictalurus punctatus) for Hg. The 2013 average $\mathrm{Hg}$ concentration for small mouth bass $(0.32 \mathrm{mg} / \mathrm{kg})$ collected at Brownlee Reservoir and for channel catfish $(0.33 \mathrm{mg} / \mathrm{kg})$ collected at the Boise River mouth, exceeded the Idaho water quality criterion $(>0.3 \mathrm{mg} / \mathrm{kg})$, the $\mathrm{Hg}$ RPTE threshold ( $>0.24 \mathrm{mg} / \mathrm{kg}$ ), and the IFCAP action level $(>0.22 \mathrm{mg} / \mathrm{kg})$. Average $\mathrm{Hg}$ concentrations in fish collected in 2014 or 2015 did not exceed evaluation criteria for any of the species assessed.

Selenium (Se) analysis was conducted on one composite fish tissue sample per site to assess general concentrations and to provide information for future risk assessments. Composite concentrations of Se in fish tissue collected between 2013 and 2015 ranged from 0.07 and $0.49 \mathrm{mg} / \mathrm{kg}$ wet weight with the highest concentration collected from smallmouth bass from the Snake River near Murphy, and the lowest from mountain whitefish from the Boise River at Eckert Road.

\section{Introduction}

Mercury $(\mathrm{Hg})$ is a global pollutant that ultimately makes its way into every aquatic ecosystem through the hydrologic cycle. Atmospheric deposition of inorganic $\mathrm{Hg}$ contributes the vast majority of $\mathrm{Hg}$ to aquatic systems, although geologic sources and point-source pollution also may contribute to $\mathrm{Hg}$ loading. Once it is in aquatic systems, inorganic $\mathrm{Hg}$ may become methylated through microbial sulfate reduction (Fitzgerald and Lamborg, 2007) and other microbially mediated reactions. Methylmercury $(\mathrm{MeHg})$ is by far the more bioavailable and toxic form of $\mathrm{Hg}$; and, once $\mathrm{Hg}$ has moved through aquatic food chains into predatory fish, almost all Hg present in fish tissue is MeHg. In turn, sport fish that are most commonly caught and consumed by subsistence or recreational anglers tend to be predatory fish. As a result of these dynamics, risks of $\mathrm{MeHg}$ exposure to humans are largely through consumption of fish (U.S. Environmental Protection Agency, 2001).

The U.S. Environmental Protection Agency (USEPA) recommended water-quality criterion for $\mathrm{MeHg}$ is expressed as a concentration in fish-tissue (wet-weight $\mathrm{MeHg}$ in fish tissue). The $\mathrm{MeHg}$ criterion is based on wet weight, appropriately reflecting the nature of fish destined for human consumption. In 2005, Idaho Department of Environmental Quality (IDEQ) adopted USEPA's fishtissue criterion of $0.3 \mathrm{mg}$ based on a $17.5 \mathrm{~g} / \mathrm{d}$ consumption rate and published implementation guidance for the Idaho Hg water-quality standard (Idaho Department of Environmental Quality, 2005). The USEPA recently updated the national fish consumption rate to $22 \mathrm{~g} / \mathrm{d}$ for this criteria based on the results from the National Health and Nutrient Survey conducted between 2003 and 2010 (U.S. Environmental Protection Agency, 2014, 2015). Because the USEPA prefers that States use local data to determine fish consumption rates for human health criteria, in 2016 the IDEQ updated its fish consumption rate used to set water quality criteria to $66.5 \mathrm{~g} / \mathrm{d}$. All human health-based water quality were updated using the higher fish consumption rates, except $\mathrm{MeHg}$, for which the value based on the $17.5 \mathrm{~g} / \mathrm{d}$ fish consumption rate was retained (Idaho Department of Environmental Quality, 2016). 
Although the fish-tissue criterion is based on methylmercury ( $\mathrm{MeHg}$ ), for the purposes of this study, total $\mathrm{Hg}$ is analyzed in place of $\mathrm{MeHg}$ for two reasons: (1) total $\mathrm{Hg}$ is easier and less costly for laboratories to determine than $\mathrm{MeHg}$, and (2) nearly all $\mathrm{Hg}$ present in fish muscle tissue is $\mathrm{MeHg}$ (Bloom, 1992; Hammerschmidt and others, 1999; Harris and others, 2003). Interpretation of total $\mathrm{Hg}$ as $\mathrm{MeHg}$ probably introduces a small positive bias, between 1 and 5 percent, based on comparisons shown by Bloom (1992) and by Hammerschmidt and others (1999), well within the range of expected analytical variability. In comparing fish-tissue results with the criterion, the analytical results for total $\mathrm{Hg}$ in the fish tissue should be interpreted as 100 percent $\mathrm{MeHg}$. For the remainder of this report, total $\mathrm{Hg}$ analyzed in both water and fish tissue will be referred to as $\mathrm{Hg}$ with fish tissue values reported as wet weight concentration.

The Idaho implementation guidance describes two scales of monitoring for $\mathrm{Hg}$ in fish tissue: (1) statewide ambient monitoring, and (2) facility/source monitoring. The Idaho Statewide Ambient Monitoring Program was designed to monitor concentrations of $\mathrm{Hg}$ in fish tissue that represent an integrated exposure to $\mathrm{Hg}$ throughout a water body over time (Idaho Department of Environmental Quality, 2005). The Idaho Statewide Ambient Monitoring Program began collecting fish tissue in 2004 and was discontinued in 2009 because of funding constraints (Essig and Kosterman, 2008; Essig, 2010). The facility/source monitoring is targeted at potential local sources. The USEPA Office of Wastewater Management in partnership with the State of Idaho manages the National Pollution Discharge and Elimination System (NPDES) to help track and manage permits for point-source dischargers (U.S. Environmental Protection Agency, 2012a). Certain NPDES permittees are required to analyze for $\mathrm{Hg}$ in effluent and in fish that inhabit the receiving waterbodies (Idaho Department of Environmental Quality, 2005).

The 2005 IDEQ implementation guidance document requires NPDES permittees to provide data for $\mathrm{Hg}$ in fish tissue under the Reasonable Potential To Exceed (RPTE) process (Idaho Department of Environmental Quality, 2005). The RPTE threshold is designed to protect people that consume fish and is based on an average $\mathrm{Hg}$ concentration from 10 fish not to exceed 80 percent of the $0.3 \mathrm{mg} / \mathrm{kg}$ Idaho criterion or greater than $0.24 \mathrm{mg} / \mathrm{kg}$ wet weight $\mathrm{Hg}$ in fish from the receiving water body. The IDEQ guidance recommends additional pollution prevention and sampling actions if the RPTE threshold is exceeded. The USEPA has included numerical Hg limitations, Hg minimization plan development, watershed-based fish tissue and water $\mathrm{Hg}$ sampling, and annual reporting requirements in the City of Boise's two effluent permits for the Lander Street and the West Boise Wastewater Treatment Facilities (U.S. Environmental Protection Agency, 2012b, 2012c).

The Idaho Fish Consumption Advisory Program (IFCAP) issues fish advisories to protect fish consumers and has developed an action level of $0.22 \mathrm{mg} / \mathrm{kg}$ wet weight $\mathrm{Hg}$ in fish tissue. Fish consumption advisories are water body- and species-specific and are used to advise general and sensitive populations of the allowable consumption of fish obtained from Idaho waters. The geometric mean $\mathrm{Hg}$ concentration of 10 fish of a single species collected from a single water body (lake or stream) in Idaho is compared to the action level to determine if a consumption advisory should be issued.

USEPA considers a total recoverable mercury concentration of $12 \mathrm{ng} / \mathrm{L}$ in water to be the effective chronic aquatic life criterion in Idaho for the purposes of the Clear Water Act (Idaho Department of Environmental Quality, 2014, referred to as "USEPA aquatic life criteria" in this report). The City of Boise's NPDES permits require a minimum detection level for $\mathrm{Hg}$ of $0.5 \mathrm{ng} / \mathrm{L}$, sufficiently low enough to compare to USEPA criteria. 
The implicit purpose of collecting data on $\mathrm{Hg}$ in water and fish tissue at the same location is to facilitate developing fish bioaccumulation factors, which are ratios of $\mathrm{Hg}$ concentrations in tissue and water. Bioaccumulation factors (BAFs) can be useful for water-quality management, such as sitespecific implementation targets of the fish-tissue based $\mathrm{MeHg}$ water-quality criteria and total maximum daily load target development (Idaho Department of Environmental Quality, 2005; U.S. Environmental Protection Agency, 2010). For developing BAFs, it is not essential that water and fish samples are collected at the same time. Riva-Murray and others (2013) reported that, in Oregon and New York streams, the best BAF estimates came from sampling MeHg in water during the July- September growing season, regardless of when the fish were collected. In related analyses with fish, the optimal approach for estimating BAFs is to use $\mathrm{Hg}$ concentration data from at least 10 adult fish of a single species and similar length (Scudder Eikenberry and others, 2015). BAFs are currently not calculated using the data published in this report. It is the intent that this data will be combined with future datacollection efforts to calculate BAFs.

The City of Boise, in cooperation with U.S. Geological Survey (USGS), developed a multiyear water and fish tissue $\mathrm{Hg}$ monitoring plan (Mebane and MacCoy, 2013) in the Snake and Boise Rivers and Brownlee Reservoir to satisfy the watershed based fish-tissue sampling requirements contained in the city permits. The IDEQ implementation guidance (Idaho Department of Environmental Quality, 2005) encourages municipal dischargers to establish monitoring cooperatives to help fund watershedbased statewide monitoring for $\mathrm{Hg}$ in fish tissue. The USEPA further recommended that the permitting authority (which is the USEPA in Idaho as of this report) require only one study per water body (U.S. Environmental Protection Agency, 2010). The multiyear water and fish-tissue $\mathrm{Hg}$ monitoring plan (Mebane and MacCoy, 2013) was developed and intended to provide a framework for a cooperative $\mathrm{Hg}$ sampling program.

Although selenium (Se) analysis is not required for NPDES permit compliance, analysis of composite samples of fish tissue for Se was done to provide information for potential future risk assessments for a couple of reasons: (1) The relative risk of a given $\mathrm{Hg}$ concentration in fish tissue may increase when Se to $\mathrm{Hg}$ molar ratios in the tissue are less than 1, and (2) Se to $\mathrm{Hg}$ ratios are of interest in fish tissue monitoring studies and risk assessment (Khan and Wang, 2009; Essig, 2010). The potential for $\mathrm{Hg}$ toxicity reduction in the presence of certain concentrations of Se has not been considered in fish consumption advisories or in comparing to criteria for the protection of human health but may be important in the future (U.S. Environmental Protection Agency, 2001; Idaho Department of Environmental Quality, 2005).

\section{Purpose and Scope}

This report contains water-quality and fish-tissue data that meet the requirements of the $\mathrm{Hg}$ monitoring plan in the Boise and Snake Rivers and Brownlee Reservoir (Mebane and MacCoy, 2013). The data contained in this report will provide a reference to which future determinations of $\mathrm{Hg}$ in water and fish can be compared.

This report contains $\mathrm{Hg}$ in water data collected by City of Boise personnel and data for $\mathrm{Hg}$ and Se in fish tissue collected by the USGS as described in the $\mathrm{Hg}$ monitoring plan (Mebane and MacCoy, 2013). Data collected by both agencies are reported here to meet the City of Boise's NPDES permit requirements. Water samples and fish samples were collected at the same locations and near the same dates. 


\section{Site Locations}

Six sampling sites (table 1) were selected to meet specific requirements for the City of Boise NPDES permits (U.S. Environmental Protection Agency, 2012b, 2012c). Site locations (fig. 1) were required to be upstream (Eckert) and downstream (Middleton) of the city's two wastewater facilities at Lander Street and West Boise on the Boise River, near the middle of the lower Boise River watershed (Middleton), at the mouth of the Boise River (Boise mouth), in the Snake River upstream (Murphy) and downstream (Nyssa) of the mouth of the Boise River, and in the impounded section of the Snake River downstream of the Boise River confluence (Brownlee). The site downstream of both wastewater facilities, Middleton, also was used to meet the middle of the lower Boise River watershed site requirement.

The basis for multiple years of sampling is provided in the $\mathrm{Hg}$ monitoring plan (Mebane and MacCoy, 2013). In 2013 and 2015, water and fish were collected at all six sampling sites (table 1, fig. 1); in 2014, only the Middleton site was sampled (MacCoy, 2014). The sites were selected to meet specific NPDES requirements and to isolate the fish populations being sampled. There are no natural fish passage barriers between sampling sites to prevent fish migration although there are manmade diversions in the Boise River between Eckert and Middleton that act as fish passage barriers.

\section{Targeted Fish Species}

The targeted fish species were based on the Idaho Department of Environmental Quality (2005) recommendation that fish tissue samples should be representative of the $\mathrm{Hg}$ exposures likely encountered from recreational or subsistence fishing, and upon previous fish sampling at selected locations in the Boise and Snake Rivers and Brownlee Reservoir (table 2; Clark and Maret, 1998; Richter and Chandler, 2003; MacCoy, 2006).

Targeting specific fish species is inherently difficult because of fish movement and sample timing. Sampling crews were able to collect 10 individuals of a targeted fish species of edible size at each site in all years except 2014 at Middleton where 2 fish were less than $25 \mathrm{~cm}$, and 2015 at the Boise mouth where only 6 fish were collected. Sampling at Murphy provided an opportunity to collect samples of two targeted fish species, smallmouth bass and channel catfish in 2013 and 2015. Smallmouth bass and channel catfish are important sport fish in the Snake River and these samples will provide a much needed comparison of $\mathrm{Hg}$ in fish tissue between species and sites (fig. 2).

\section{Field Sampling Procedures}

Water samples were collected by City of Boise personnel using low-level Hg surface-water sampling protocols (City of Boise, Public Works field standard operating procedures, written commun., March 12, 2014) following collection and quality-control procedures similar to those described in Lewis and Brigham (2004) and Essig (2010). Precleaned $200 \mathrm{~mL}$ glass bottles were used to collect dip water samples. Samples were placed on ice and delivered to the Boise City Public Works Water Quality Laboratory, within the same day. Field blanks were collected at some sites for quality control as described in Wilde (2006, section 4.3 "Quality-Control Samples"). 
Fish-tissue sampling was conducted during low-flow conditions to reduce hazards from maneuvering the boat or raft in high water velocities. Fish were captured by electrofishing; additional information on electrofishing sampling safety, sampling permit requirements, and justification for sampling outside the summer season is given in the Hg monitoring plan (Mebane and MacCoy, 2013).

Procedures for collecting and processing fish for analysis of $\mathrm{Hg}$ are similar to those outlined in Scudder and others (2008). Sampling procedures specific to this project are given here. Boat and raft electrofishing were used to collect targeted fish species at a site. Fish of edible size (typically greater than $25 \mathrm{~cm}$ in length, or for smallmouth bass, greater than $30 \mathrm{~cm}$ in length) were placed in a live well. When at least 10 individuals of the same species were collected, the fish were weighed, measured, euthanized, and placed in separate clean, clear, zip-seal bags on wet ice. Fish were transported to the sample preparation area at the USGS Idaho Water Science Center in Boise and frozen to minimize possible loss of sample integrity. When processed, two skinless fillets were obtained from each fish, one for the primary sample and the second retained frozen as a backup sample for $\mathrm{Hg}$ analysis.

Approximately $5 \mathrm{~g}$ of tissue from each of the 10 fish collected from a site was composited for Se analysis. The backup samples were retained until data were received from the laboratory and reviewed. Fish-tissue samples for Hg analysis were shipped on dry ice to the USGS Mercury Research Laboratory (USGS MRL) in Middleton, Wisconsin. Fish-tissue samples for Se analysis were shipped on dry ice to the USGS National Water Quality Laboratory (NWQL) in Denver, Colorado.

\section{Laboratory Methods}

\section{Mercury in Water}

Unfiltered water samples were analyzed for $\mathrm{Hg}$ using laboratory methods consistent with USEPA Method 1631 E (U.S. Environmental Protection Agency, Office of Water, 2002) by the Boise City Public Works Water Quality Laboratory. This method provided a minimum detection level of 0.2 ng/L.

\section{Mercury in Fish Tissue}

The USGS MRL provided analysis of $\mathrm{Hg}$ in fish tissue consistent with USEPA Method 7473 (U.S. Environmental Protection Agency, 2007). The USGS MRL has determined that this method has a minimum detection limit of $0.008 \mathrm{mg} / \mathrm{kg}$ dry weight, based on a 20-50 mg sample size for their laboratory equipment. The detection limit is sufficiently low to quantify $\mathrm{Hg}$ concentrations in fish tissue at less than $0.30 \mathrm{mg} / \mathrm{kg}$ wet weight. Additional USGS MRL quality-assurance procedures can be found on their website Error! Hyperlink reference not valid.(U.S. Geological Survey, 2013)

\section{Selenium in Fish Tissue}

A sample size of less than $20 \mathrm{~g}$ is needed for Se analysis. The composite of a portion of tissue from each of 10 fish from a site resulted in a sufficient sample size. NWQL analysis of Se in tissue used methods by Garbarino and others (2006). This method provided a minimum level of detection of 0.1 $\mathrm{mg} / \mathrm{kg}$ dry weight. The $\mathrm{Hg}$ monitoring plan (Mebane and MacCoy, 2013) specified a composite of at least three fish per site. The composite of 10 fish provided a more than adequate sample for general Se screening. 


\section{Results}

\section{Data-Quality Objectives}

All data-quality objectives were met for this study and provided reliable $\mathrm{Hg}$ concentrations in water and in fish-tissue data collected from the Snake and Boise Rivers and Brownlee Reservoir. The data-quality objectives of this monitoring study are listed here:

1. The fish collected represent the species and size ranges likely to be caught and consumed by recreational or subsistence anglers in the vicinity of the sampling sites.

2. Sample processing, handling, storing, and shipping to the laboratory used sufficient qualityassurance measures to avoid introducing sample contamination or bias to the data.

3. Laboratory analytical techniques had sufficiently low detection limits to quantify $\mathrm{Hg}$ concentrations in fish tissue at less than $0.24 \mathrm{mg} / \mathrm{kg}$ wet weight (Idaho RPTE threshold).

4. Quality-control samples were analyzed to provide accuracy and precision information for the fish-tissue samples collected (table 3). The accuracy of the data was within 20 percent of the most probable value for certified reference tissues for $\mathrm{Hg}$, and the precision (repeatability) of the data was within 20 percent relative standard deviation in laboratory replicate analyses.

5. Following review, fish-tissue data were made available to the public and environmental management agencies through the online USGS National Water Information System (NWIS) and in this report.

6. Mercury concentrations in water quality-control samples are presented with the water sample results (table 4) and include field blanks and laboratory matrix spikes results. $\mathrm{Hg}$ concentrations in all but one field blank were near or less than the laboratory detection limit $(0.2 \mathrm{ng} / \mathrm{L})$. Matrix spike recovery of $\mathrm{Hg}$ in water samples ranged from 94.8 to 100.5 percent, well within the required recovery of 71-125 percent of the theoretical value. The relative percent difference of matrix spike duplicates required by USEPA is less than 24 percent (U.S. Environmental Protection Agency, Office of Water, 2002). The observed relative percent difference of the matrix spike recovery ranged from 0.41 to 8.1 percent, also within the USEPA's criteria.

\section{Mercury in Water}

$\mathrm{Hg}$ in water was collected at all six sampling sites on the Boise and Snake Rivers and Brownlee Reservoir. Hg concentrations, field blank concentrations, and laboratory matrix spike recovery data are shown in table 4. Concentrations of $\mathrm{Hg}$ in water were between 0.48 and $8.8 \mathrm{ng} / \mathrm{L}$, with the highest concentration from Brownlee Reservoir. All samples were less than the USEPA aquatic life criteria (12 ng/L, U.S. Environmental Protection Agency, 1985; Idaho Department of Water Quality, 2014). All field blanks were near or less than the detection level except for the sample taken at Boise mouth (detection of $0.70 \mathrm{ng} / \mathrm{L} \mathrm{Hg}$ ). With that one exception, the blank values, as well as the laboratory spike recovery, were within data-quality objectives. 


\section{Fish Species, Size, and Tissue Mercury Concentrations}

The concentration of $\mathrm{Hg}$ in fish tissue, as well as the length and weight of the fish collected from the Boise and Snake Rivers and Brownlee Reservoir are shown in table 5. A graphical summary of $\mathrm{Hg}$ concentrations in all fish from all sites is shown in figure 3, and summaries of individual fish length and $\mathrm{Hg}$ concentrations are shown in figure 4. All fish-tissue data presented in this report can be accessed on the USGS NWIS websiteError! Hyperlink reference not valid. (U.S. Geological Survey, 2014).

Although this study was not designed to compare fish size to $\mathrm{Hg}$ concentration, graphical summaries of fish size and $\mathrm{Hg}$ concentration are presented, as they may be useful for fish advisory development.

Rainbow trout were collected at the upstream site (Eckert) in 2015. Total fish lengths for rainbow trout were between 250 and $390 \mathrm{~mm}$, and median $\mathrm{Hg}$ concentration was 0.02 . Mean concentrations did not exceed the Idaho water-quality criterion, RPTE threshold level, or the IFCAP action level (table 5, fig. 3).

Mountain whitefish were collected at the upstream site (Eckert) in 2013 and at the site downstream of the City of Boise wastewater facilities on the Boise River (Middleton, fig. 1) in 2013, 2014, and 2015. Total fish lengths for mountain whitefish were between 135 and $506 \mathrm{~mm}$, with primarily larger fish sampled from Eckert (table 5, fig. 4A). Median $\mathrm{Hg}$ concentrations in mountain whitefish were $0.18 \mathrm{mg} / \mathrm{kg}$ at Eckert and ranged from 0.11 to $0.18 \mathrm{mg} / \mathrm{kg}$ at Middleton for the 3 sample years. Mean concentrations in mountain whitefish did not exceed the Idaho water-quality criterion, RPTE threshold level, or the IFCAP action level (table 5, fig. 3).

Smallmouth bass were collected from Murphy, the Snake River site upstream of the mouth of the Boise River in 2013 and 2015 and from Brownlee Reservoir in 2013. Total fish lengths were between 300 and $452 \mathrm{~mm}$, with the largest fish sampled from Brownlee (table 5, fig. 4B). Median $\mathrm{Hg}$ concentrations in smallmouth bass were similar at Murphy between sample years $(0.16$ and 0.17 $\mathrm{mg} / \mathrm{kg})$. Only the $\mathrm{Hg}$ in Brownlee smallmouth bass $(0.32 \mathrm{mg} / \mathrm{kg})$ collected in 2013 exceeded the Idaho water-quality criterion, RPTE threshold level, and the IFCAP action level (table 5, fig. 3).

Channel catfish were collected from the Boise mouth, Murphy, and Nyssa sites in 2013 and 2015; and from Brownlee in 2015. Individual fish lengths were between 483 and $720 \mathrm{~mm}$ with the largest individual fish sampled from Murphy (table 5). There was no discernible relation between fish length and $\mathrm{Hg}$ concentrations in channel catfish (fig. 4C). For the 2 years of sampling, the median $\mathrm{Hg}$ concentrations in channel catfish tissue were 0.24 and $0.28 \mathrm{mg} / \mathrm{kg}$ from Boise mouth, 0.11 and 0.18 $\mathrm{mg} / \mathrm{kg}$ at Murphy, and 0.13 and $0.14 \mathrm{mg} / \mathrm{kg}$ from Nyssa; with a single median concentration of 0.16 $\mathrm{mg} / \mathrm{kg}$ from Brownlee collected in 2015 (table 5, fig. 3). Median Hg concentrations were similar between the channel catfish $(0.18 \mathrm{mg} / \mathrm{kg})$ and smallmouth bass from Murphy $(0.17 \mathrm{mg} / \mathrm{kg})$ in 2013 , but in 2015 median concentrations, although lower than in 2013, were higher in smallmouth bass $(0.16$ $\mathrm{mg} / \mathrm{kg})$ than channel catfish $(0.11 \mathrm{mg} / \mathrm{kg})$. Only the channel catfish collected in 2013 at Boise mouth site exceeded the Idaho water-quality criterion, RPTE threshold level, and the IFCAP action level (table 5, fig. 3). Although the average and geometric mean concentrations were calculated for the channel catfish collected in 2015 from the Boise mouth, 0.23 and $0.22 \mathrm{mg} / \mathrm{kg}$, respectively (table 5), the values were not compared to RPTE threshold and IFCAP action level because fewer than 10 catfish were collected. 


\section{Selenium in Fish Tissue}

The concentration of Se in composite fish-tissue samples collected from the Boise and Snake Rivers and Brownlee Reservoir are given in table 6. Percent water, percent solids, and wet weight concentrations are given to better compare the results to $\mathrm{Hg}$ wet-weight concentrations. Composite concentrations collected from 2013 to 2015 were between 0.07 and $0.49 \mathrm{mg} / \mathrm{kg}$ wet weight, with the lowest concentration in mountain whitefish from Eckert and the highest concentration in smallmouth bass collected from Murphy. Molar ratios of Se to Hg ranged from 0.99 to 25 (table 6).

\section{Summary}

Water samples and sport fish of edible size were collected for $\mathrm{Hg}$ analysis from six sites in the Boise and Snake Rivers and Brownlee Reservoir in 2013 and 2015, and from one site in 2014, to meet a portion of the City of Boise's National Pollution Discharge and Elimination System Hg monitoring requirements. Water samples were collected at each site to closely coincide with fish sampling efforts. Fish collected at each of the sites represent typical sport fish likely to be taken by recreational and subsistence anglers for consumption. Average and geometric mean $\mathrm{Hg}$ concentrations in fish from the Boise mouth $(0.33$ and $0.28 \mathrm{mg} / \mathrm{kg}$ in channel catfish) and Brownlee $(0.32$ and $0.32 \mathrm{mg} / \mathrm{kg}$ in small mouth bass) collected in 2013 exceeded Idaho's water quality criteria of $0.30 \mathrm{mg} / \mathrm{kg}$, the IDEQs RPTE threshold of $<0.24 \mathrm{mg} / \mathrm{kg}$, and IFCAP action level of $0.22 \mathrm{mg} / \mathrm{kg}$ wet weight. There were no exceedances of these fish tissue criteria in 2015.

Total $\mathrm{Hg}$ concentrations in unfiltered water samples ranged from 0.48 to $8.8 \mathrm{ng} / \mathrm{L}$ total $\mathrm{Hg}$, with the highest Brownlee Reservoir in 2013. All Hg concentrations in water samples were less than the U.S. Environmental Protection Agency (USEPA) Hg chronic aquatic life criterion of $12 \mathrm{ng} / \mathrm{L}$.

Composite concentrations of Se in fish tissue collected between 2013 and 2015 were between 0.07 and $0.49 \mathrm{mg} / \mathrm{kg}$ wet weight with the highest concentration collected from smallmouth bass from the Snake River near Murphy and the lowest from mountain whitefish from the Boise River at Eckert Road. Se composite samples collected in this study provide information for comparing Se concentrations between species and for possible future use in fish consumption advisories. 


\section{References Cited}

Bloom, N.S., 1992, On the chemical form of mercury in edible fish and marine invertebrate tissue: Canadian Journal of Fisheries and Aquatic Sciences, v. 49, no. 5, p. 1010-1017, accessed March 10, 2014, at http://dx.doi.org/10.1139/f92-113.

Clark, G.M., and Maret, T.R., 1998, Organochlorine compounds and trace elements in fish tissue and bed sediments in the Lower Snake River Basin, Idaho and Oregon: U.S. Geological Survey WaterResources Investigations Report 98-4103, 35 p. [Also available at http://pubs.er.usgs.gov/publication/wri984103.]

Essig, D.A., 2010, Arsenic, mercury, and selenium in fish tissue and water from Idaho's major riversA statewide assessment: Idaho Department of Environmental Quality, accessed February 22, 2016, at http://www.deq.idaho.gov/water-quality/surface-water/mercury.aspx.

Essig, D.A., and Kosterman, M.A., 2008, Arsenic, mercury, and selenium in fish tissue from Idaho lakes and reservoirs - A statewide assessment: Idaho Department of Environmental Quality, 80 p.

Fitzgerald, W.F., and Lamborg, C.H., 2007, Geochemistry of mercury in the environment: Elsevier, Treatise on Geochemistry, p. 1-47, http://www.sciencedirect.com/science/referenceworks/9780080437514.

Garbarino, J.R., Kanagy, L.K., and Cree, M.E., 2006, Determination of elements in natural-water, biota, sediment, and soil samples using collision/reaction cell inductively coupled plasma-Mass Spectrometry: U.S. Geological Survey Techniques and Methods, book 5, chap. B1, 88 p., http://pubs.usgs.gov/tm/2006/tm5b1/.

Hammerschmidt, C.R., Wiener, J.G., Frazier, B.E., and Rada, R.G., 1999, Methylmercury content of eggs in yellow perch related to maternal exposure in four Wisconsin lakes: Environmental Science and Technology, v. 33, no. 7, p. 999-1,003, accessed February 22, 2016, at http://dx.doi.org/10.1021/es980948h.

Harris, H.H., Pickering, I.J., and George, G.N., 2003, The chemical form of mercury in fish: Science, v. 301, no. 5637, p. 1,203, accessed February 22, 2016, at http://dx.doi.org/10.1126/science. 1085941.

Idaho Department of Environmental Quality, 2005, Implementation guidance for the Idaho mercury water quality criteria: Boise, Idaho, Idaho Department of Environmental Quality, 212 p., accessed February 22, 2016, at http://www.deq.idaho.gov/water-quality/surface-water/mercury.aspx .

Idaho Department of Environmental Quality, 2014, EPA actions on proposed standards: Web page, accessed February 22, 2016, at http://www.deq.idaho.gov/epa-actions-on-proposed-standards.

Idaho Department of Environmental Quality, 2016, Water quality—Docket no. 58-0102-1201—Final rule: Web page, accessed April 12, 2016, at http:/www.deq.idaho.gov/58-0102-1201.

International Atomic Energy Agency, 2003, Trace elements and methylmercury in fish tissue: Reference sheet IAEA-407, accessed May 2, 2014, at http://www.iaea.org/nael/refmaterial/iaea407.pdf.

Khan, M.A.K., and Wang, F., 2009, Mercury-selenium compounds and their toxicological significance-Toward a molecular understanding of the mercury-selenium antagonism: Environmental Toxicology and Chemistry, v. 28, no. 8, p. 1567-1577, http://dx.doi.org/10.1897/08375.1 . 
Lewis, M.E., and Brigham, M.E., 2004, Low-level mercury, in Wilde, F.D., Radtke, D.B., Gibs, J., and Iwatsubo, R.T., eds., Chapter A5 processing of water samples-National field manual for the collection of water-quality data: U.S. Geological Survey Techniques of Water-Resources Investigations, book 9, accessed March 10, 2014, at http://pubs.water.usgs.gov/twri9A5/.

MacCoy, D.E., 2006, Fish communities and related environmental conditions of the lower Boise River, southwestern Idaho, 1974-2004: U.S. Geological Survey Scientific Investigations Report 2006-5111, 36 p. [Also available at http://pubs.usgs.gov/sir/2006/5111/.]

MacCoy, D.E., 2014, Mercury concentrations in water, and mercury and selenium concentrations in fish from Brownlee Reservoir and selected sites in Boise and Snake Rivers, Idaho and Oregon, 2013: U.S. Geological Survey Open-File Report 2014-1099, 26 p.. [Also available at http://dx.doi.org/10.3133/ofr20141099.]

Mebane, C.A., and MacCoy, D.E., 2013, Monitoring plan for mercury in fish tissue and water from the Boise River, Snake River, and Brownlee Reservoir, Idaho and Oregon: U.S. Geological Survey OpenFile Report 2013-1068, 24 p. [Also available at http://pubs.usgs.gov/of/2013/1068/.]

Richter, T.J., and Chandler, J.A., 2003, Water-level impacts to spawning smallmouth bass, crappie spp., and channel catfish, in Richter, T.J., ed., Hells Canyon complex resident fish study, revised 2003: Boise, Idaho, Idaho Power Company, 76 p., accessed March 10, 2014, at http://www.idahopower.com/pdfs/Relicensing/hellscanyon/hellspdfs/techappendices/Aquatic/e31_05_ ch01.pdf.

Riva-Murray, K., Bradley, P.M., Scudder Eikenberry, B.C., Knightes, C.D., Journey, C.A., Brigham, M.E., and Button, D.T., 2013, Optimizing stream water mercury sampling for calculation of fish bioaccumulation factors: Environmental Science and Technology, v. 47, no. 11, p. 5,904-5,912, http://dx.doi.org/10.1021/es303758e.

Scudder, B.C., Chasar, L.C., DeWeese, L.R., Brigham, M.E., Wentz, D.A., and Brumbaugh, W.G., 2008, Procedures for collecting and processing aquatic invertebrates and fish for analysis of mercury as part of the National Water-Quality Assessment Program: U.S. Geological Survey Open-File Report 2008-1208, 34 p. [Also available at http://pubs.usgs.gov/of/2008/1208/.]

Scudder Eikenberry, B.C., Riva-Murray, K., Knightes, C.D., Journey, C.A., Chasar, L.C., Brigham, M.E., and Bradley, P.M., 2015, Optimizing fish sampling for fish-mercury bioaccumulation factors: Chemosphere, v. 135, p. 467-473, http://dx.doi.org/10.1016/j.chemosphere.2014.12.068.

U.S. Environmental Protection Agency, 1985, Ambient water quality criteria for mercury-1984: U.S. Environmental Protection Agency, EPA 440/5-84-026, 144 p., accessed April 20, 2016, at https://www.epa.gov/nscep.

U.S. Environmental Protection Agency, 2001, Water quality criterion for the protection of human health-Methylmercury: U.S Evironmental Protection Agency, EPA-823-R-01-001, 303 p., accessed March 10, 2014, at http:/www.epa.gov/waterscience/criteria/methylmercury/.

U.S. Environmental Protection Agency, 2007, Mercury in solids and solutions by thermal decomposition, amalgamation, and atomic absorption spectrophotometry: U.S. Environmental Protection Agency, EPA Method 7473 (SW-846), accessed March 10, 2014, at www.epa.gov/osw/hazard/testmethods/sw846/pdfs/7473.pdf.

U.S. Environmental Protection Agency, 2010, Guidance for implementing the January 2001 methylmercury water quality criteria: U.S. Environmental Protection Agency, EPA-823-R-10-001, 221 p., accessed March 10, 2014, at http:/www.epa.gov/wqc/guidance-implementing-january-2001methylmercury-water-quality-criterion . 
U.S. Environmental Protection Agency, 2012a, National Pollutant Discharge Elimination System (NPDES): Websites, accessed March 19, 2014, at http://cfpub.epa.gov/npdes/about.cfm?program_id=0.

U.S. Environmental Protection Agency, 2012b, Authorization to discharge under the National Pollutant Discharge Elimination System-Lander Street Wastewater Treatment Facility, City of Boise: U.S. Environmental Protection Agency, Permit No.: ID-002044-3, 53 p., accessed March 10, 2014, at http://yosemite.epa.gov/r10/water.nsf/NPDES+Permits/Current+ID1319.

U.S. Environmental Protection Agency, 2012c, Authorization to discharge under the National Pollutant Discharge Elimination System-West Boise Wastewater Treatment Facility, City of Boise: U.S. Environmental Protection Agency, Permit No. ID-002044-3, 52 p., accessed March 10, 2014, at http://yosemite.epa.gov/r10/water.nsf/NPDES+Permits/Current+ID1319.

U.S. Environmental Protection Agency, 2014, Estimated fish consumption rates for the U.S. population and selected subpopulations (NHANES 2003-2010): Washington, D.C. EPA -820-R-14-002, 110 p., accessed February 23, 2016, at http:/www.epa.gov/sites/production/files/2015-01/documents/fishconsumption-rates-2014.pdf.

U.S. Environmental Protection Agency, 2015, Final updated ambient water quality criteria for the protection of human health: Federal Register, v. 80, no. 124, p. 36986-36989, accessed February 23, 2016, at http://www.epa.gov/wqc/human-health-water-quality-criteria.

U.S. Environmental Protection Agency, Office of Water, 2002, Method 1631, Revision E-Mercury in water by oxidation, purge and trap, and cold vapor atomic fluorescence spectrometry: Washington, D.C., EPA-821-R-02-019, 46 p., accessed March 10, 2014, at http://water.epa.gov/scitech/methods/cwa/metals/mercury/index.cfm.

U.S. Geological Survey, 2013, USGS Mercury Research Laboratory: Website, accessed April 25, 2014, at http://wi.water.usgs.gov/mercury-lab/index.html.

U.S. Geological Survey, 2014, USGS Water-quality for Idaho: Website, accessed April 25, 2014, at http://waterdata.usgs.gov/id/nwis/qw.

Wilde, F.D., ed., 2006, Collection of water samples: U.S. Geological Survey Techniques of WaterResources Investigations, book 9, chap A4 (v. 2.0), 231 p., accessed March 10, 2014, at http://water.usgs.gov/owq/FieldManual/chapter4/html/Ch4_contents.html. 


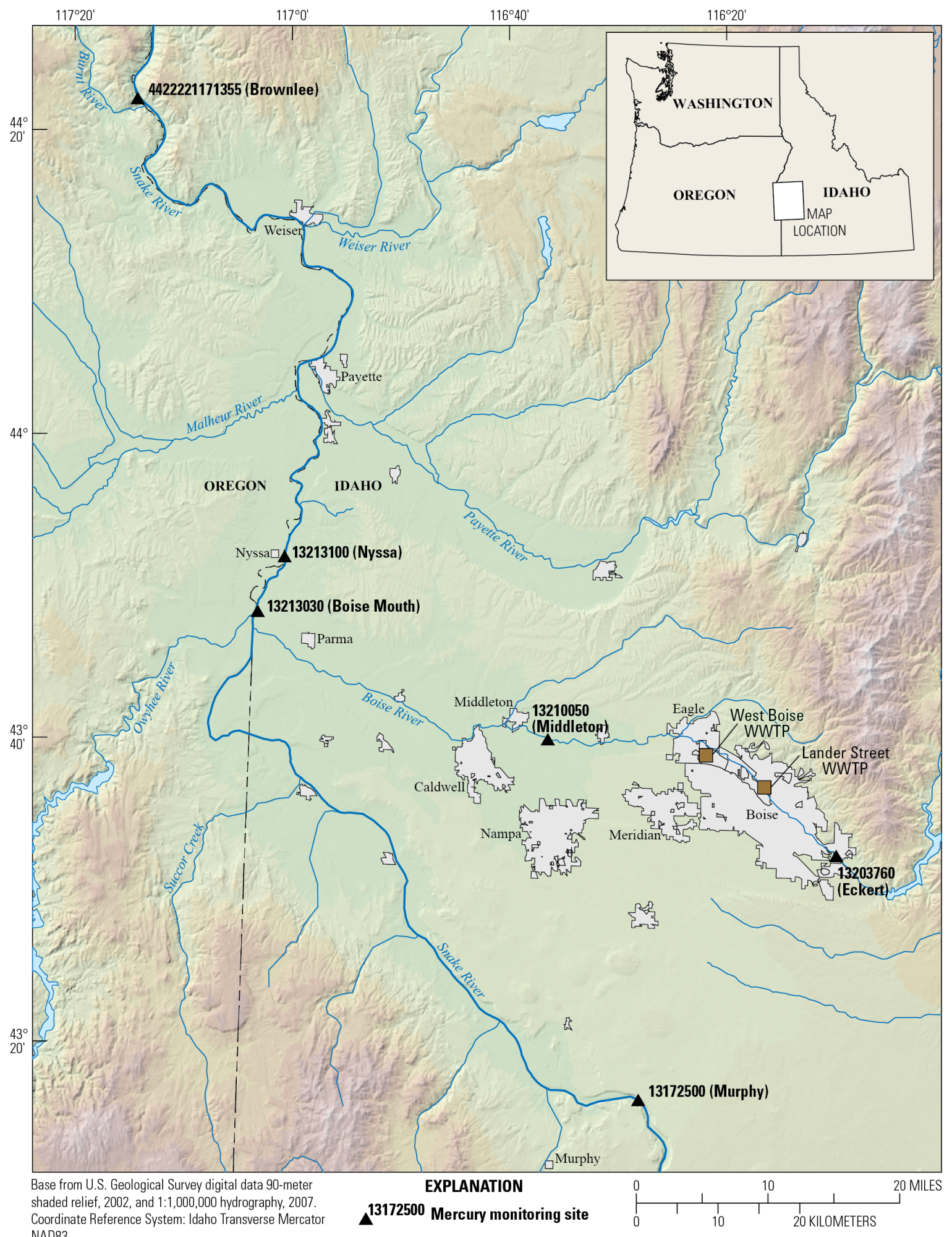

Figure 1. Map showing location of sites where water and fish tissue samples were collected for analysis of total mercury and selenium, Idaho and Oregon, 2013-15. 

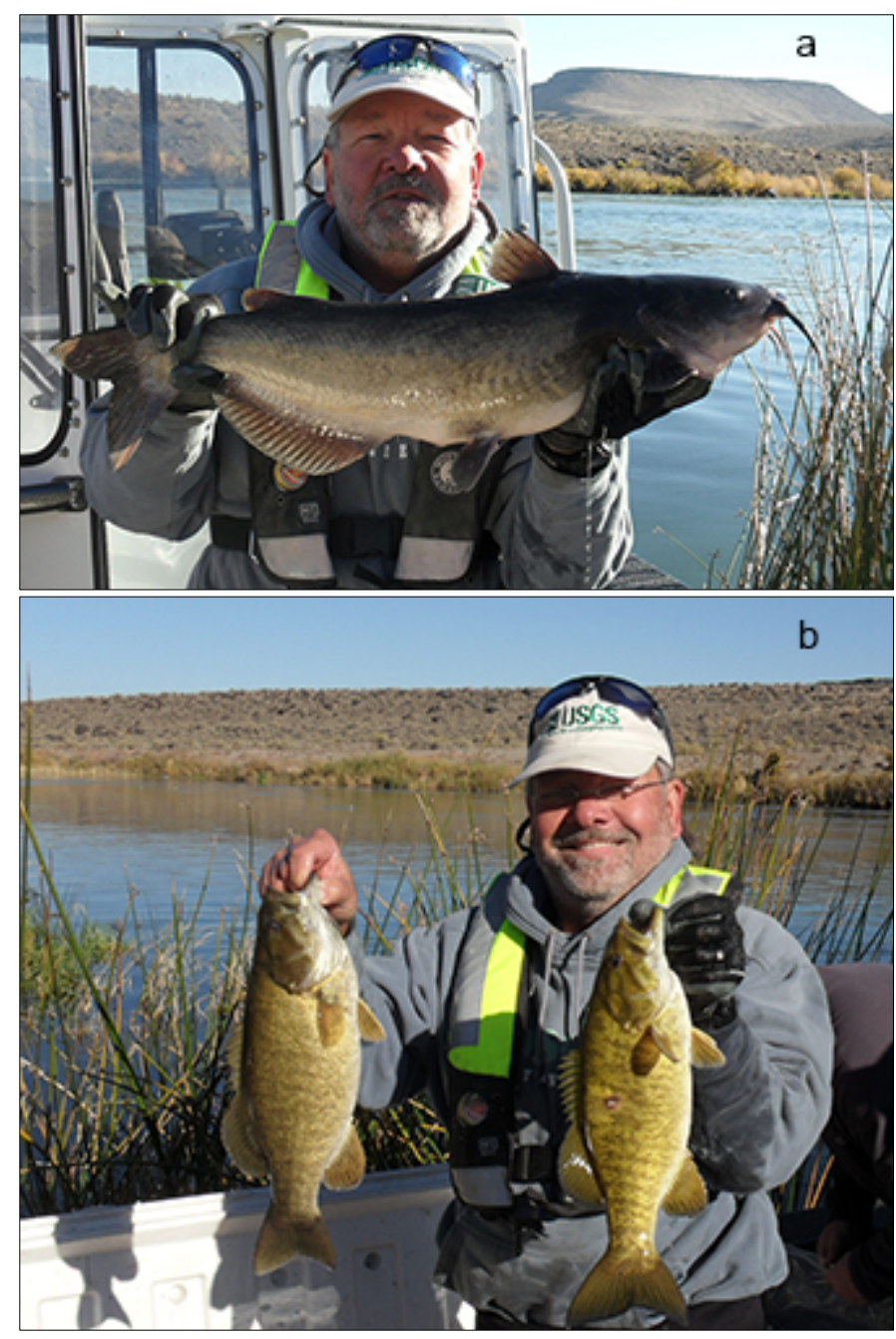

Figure 2. Photographs of channel catfish (a) and smallmouth bass (b) at the Snake River near Murphy sampling site, October 2013. (Photographs by Dorene MacCoy, U.S. Geological Survey.) 


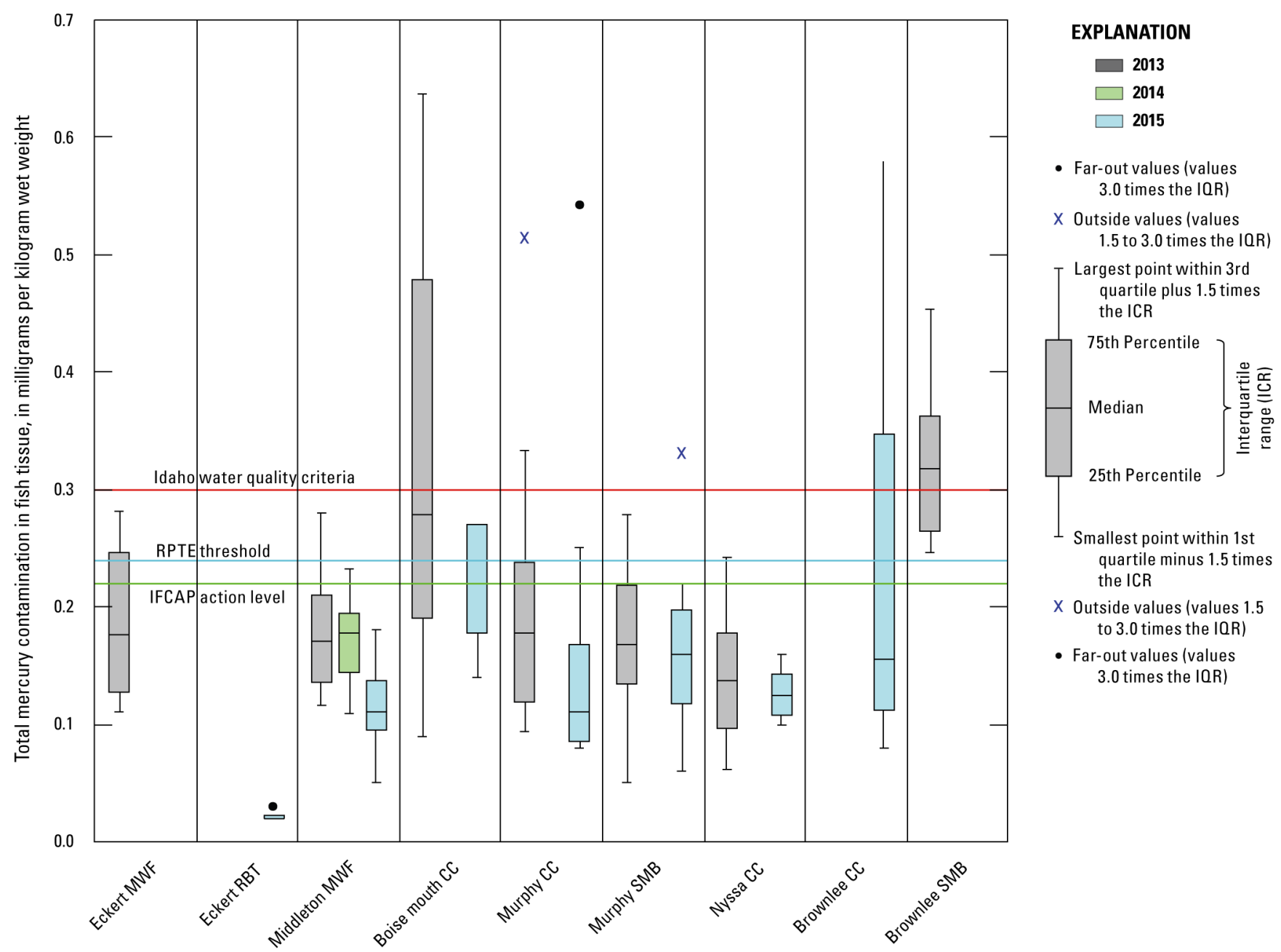

Figure 3. Boxplot showing total mercury concentrations in fish tissue collected from sites in the Boise and Snake Rivers and Brownlee Reservoir, October 2013-15, Idaho and Oregon. (CC, channel catfish; MWF, mountain whitefish; RBT, rainbow trout; SMB, smallmouth bass.) (IFCAP action level, Idaho Fish Consumption Advisory Project recommends consideration of issuing a fish advisory when the geometric mean of mercury in 10 fish exceeds $0.22 \mathrm{mg} / \mathrm{kg}$ wet weight; RPTE threshold, reasonable potential to exceed 80 percent of the ldaho mercury water-quality criterion of 0.30 milligrams per kilogram $[\mathrm{mg} / \mathrm{kg}]$ wet weight mercury or greater than $0.24 \mathrm{mg} / \mathrm{kg}$ in an average of 10 fish). Site names are shown in table 1. 


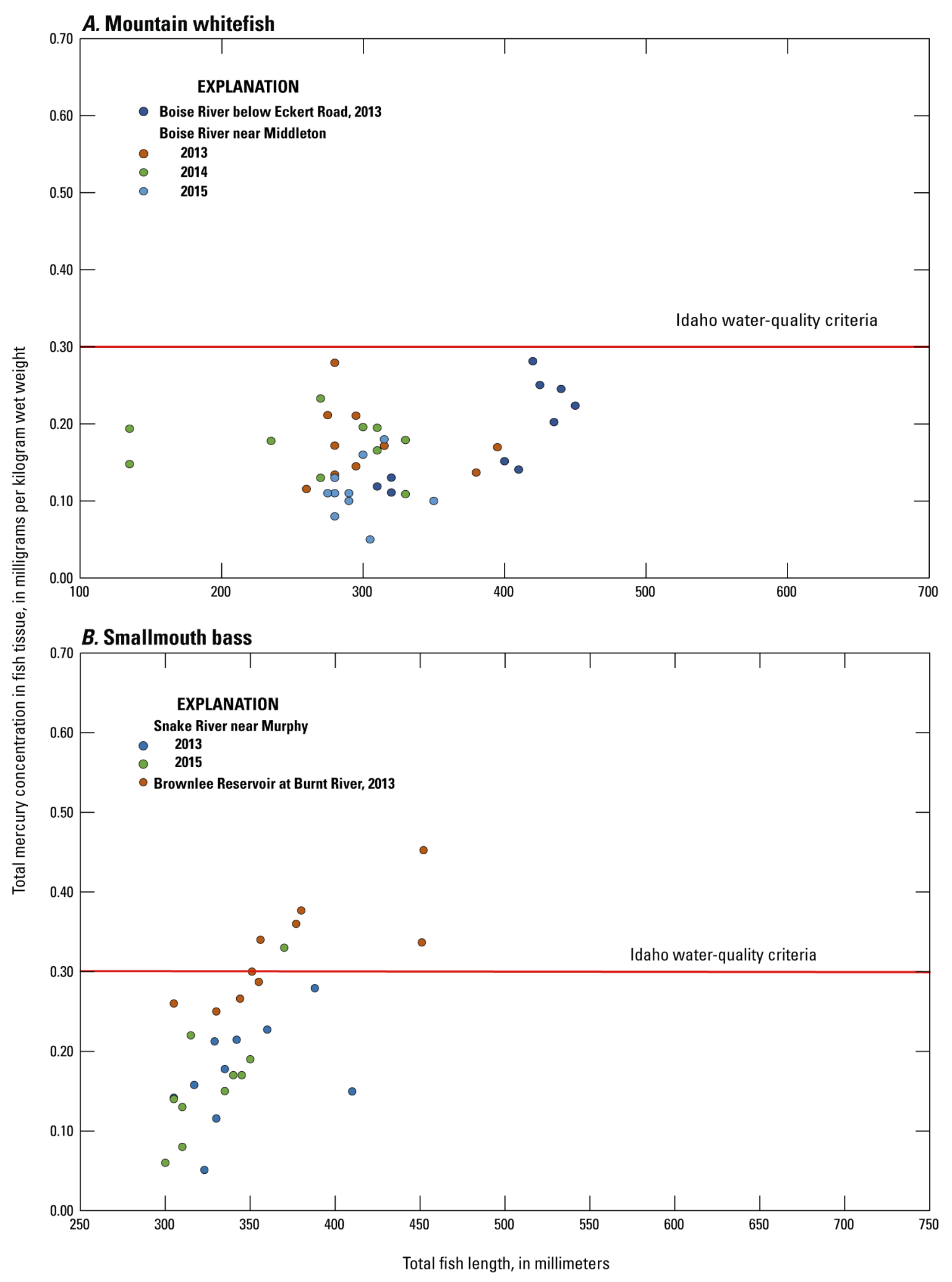

Figure 4. Graphs showing total mercury tissue concentrations and total length of mountain whitefish $(A)$, smallmouth bass $(B)$ channel catfish $(C)$ and rainbow trout $(D)$ in samples from the Boise and Snake Rivers and Brownlee Reservoir, Idaho and Oregon, 2013-15. 


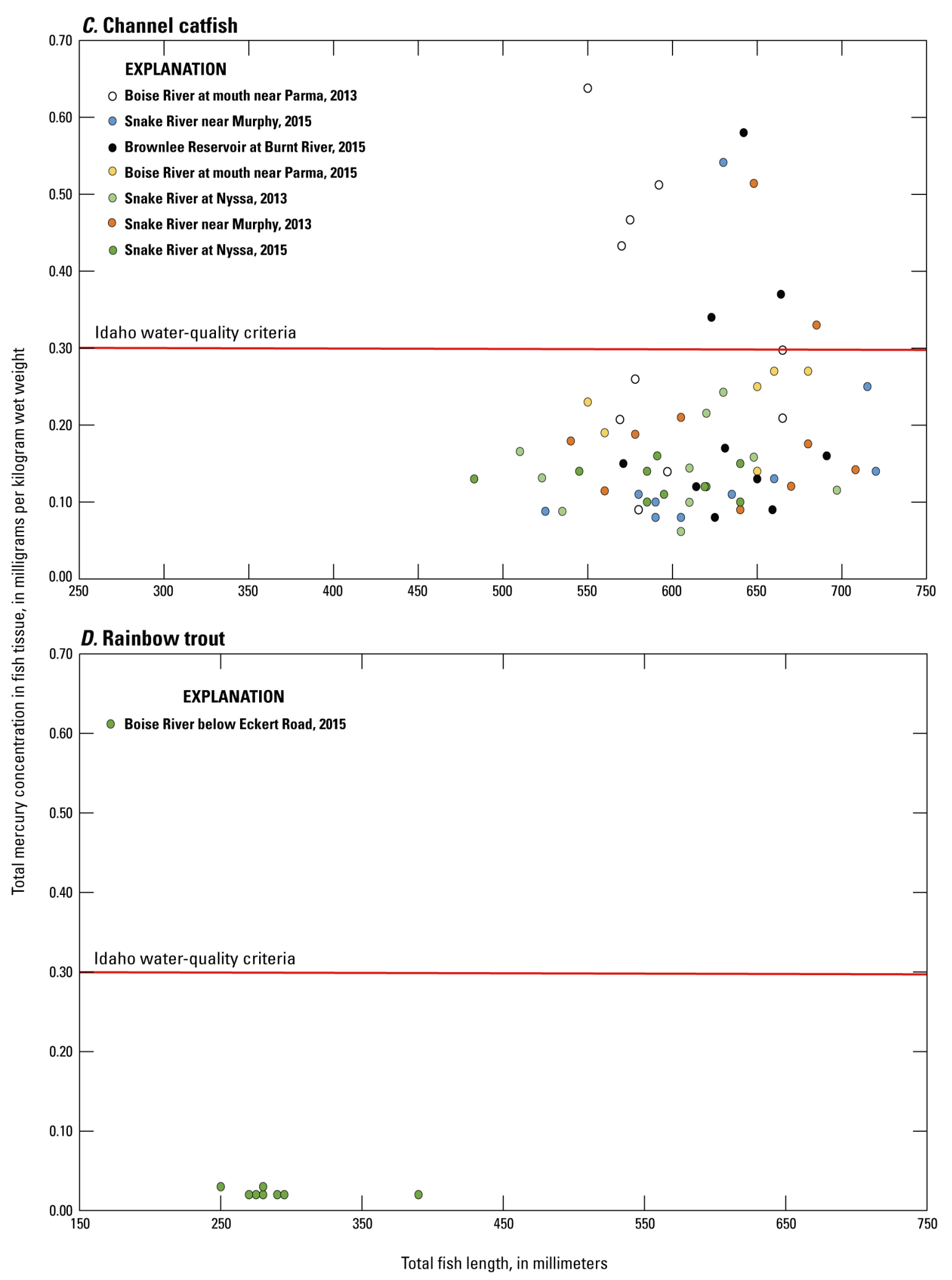

Figure 4.-Continued 
Table 1. Sites in the Boise and Snake Rivers and Brownlee Reservoir where water and fish samples were collected for mercury analysis, Idaho and Oregon, 2013-15.

[Site locations are shown in figure 1. NAD83, North American Datum of 1983]

\begin{tabular}{lllll}
\hline $\begin{array}{c}\text { USGS site } \\
\text { identification }\end{array}$ & \multicolumn{1}{c}{ Site name } & Site short name & $\begin{array}{c}\text { Decimal latitude } \\
\text { (NAD83) }\end{array}$ & $\begin{array}{c}\text { Decimal longitude } \\
\text { (NAD83) }\end{array}$ \\
\hline 13203760 & Boise River at Eckert Road, near Boise, Idaho & Eckert & 43.56572 & -116.13205 \\
13210050 & Boise River near Middleton, Idaho & Middleton & 43.68488 & -116.57374 \\
13213030 & Boise River at mouth, near Parma, Idaho & Boise mouth & 43.81516 & -117.02043 \\
13172500 & Snake River near Murphy, Idaho & Murphy & 43.29183 & -116.42094 \\
13213100 & Snake River at Nyssa, Oregon & Nyssa & 43.87611 & -116.9825 \\
4422221171355 & Brownlee Reservoir at Burnt River, Oregon & Brownlee & 44.37266 & -117.23295 \\
\hline
\end{tabular}

Table 2. Targeted fish species in the Boise and Snake Rivers and Brownlee Reservoir, Idaho and Oregon.

[Site locations are shown in figure 1. Full site names are listed in table 1. Species in bold were collected at sites for tissue analysis]

\begin{tabular}{|c|c|c|}
\hline $\begin{array}{c}\text { USGS site } \\
\text { identification }\end{array}$ & Site name & Expected species \\
\hline 13203760 & Eckert & $\begin{array}{l}\text { Mountain whitefish (Prosopium williamsoni), brown trout (Salmo trutta), } \\
\text { rainbow trout (Oncorhynchus mykiss) }\end{array}$ \\
\hline 13210050 & Middleton & $\begin{array}{l}\text { Mountain whitefish, brown trout, largemouth bass (Micropterus salmoides), } \\
\text { smallmouth bass (Micropterus dolomieui) }\end{array}$ \\
\hline 13213030 & Boise mouth & $\begin{array}{l}\text { Mountain whitefish, largemouth bass, smallmouth bass, channel catfish } \\
\text { (Ictalurus punctatus) }\end{array}$ \\
\hline 13172500 & Murphy & Smallmouth bass, largemouth bass, channel catfish \\
\hline 13213100 & Nyssa & Smallmouth bass, mountain whitefish, largemouth bass, channel catfish \\
\hline 4422221171355 & Brownlee & Smallmouth bass, crappie spp. (Pomoxis sp.), largemouth bass, channel catfish \\
\hline
\end{tabular}


Table 3. Quality-control sample results for analysis of total mercury in fish from the Boise and Snake Rivers and Brownlee Reservoir, Idaho and Oregon, October 2013-15.

[Certified reference material from the International Atomic Energy Agency, laboratory identification number beginning with IAEA (2003); a description of IAEA-407 is available at http://www.iaea.org/nael/refmaterial/iaea407.pdf. Triplicate samples from a single fish at a sampling site (laboratory identification samples beginning with MSC) were analyzed separate from the original sample for laboratory method repeatability (precision) and reported as relative standard deviation $(\mathrm{RSD})$, RSD $=$ Standard deviation of the three replicate concentrations divided by the average of those replicates. Abbreviation: ng/g, nanograms per gram]

\begin{tabular}{|c|c|c|c|c|}
\hline $\begin{array}{l}\text { Laboratory } \\
\text { identification }\end{array}$ & Date of analysis & $\begin{array}{l}\text { Mercury, } \\
\text { ng/g dry } \\
\text { weight }\end{array}$ & $\begin{array}{l}\text { Laboratory } \\
\text { detection limit, } \\
\text { ng/g dry } \\
\text { weight }\end{array}$ & $\begin{array}{c}\text { Certified } \\
\text { reference } \\
\text { material } \\
\text { percent } \\
\text { recovery }\end{array}$ \\
\hline IAEA-407 & $2 / 18 / 2014$ & 213 & 2.99 & 96 \\
\hline IAEA-407 & $2 / 18 / 2014$ & 221 & 3.4 & 99.6 \\
\hline IAEA-407 & $2 / 18 / 2014$ & 224 & 3.56 & 101 \\
\hline IAEA-407 & $2 / 18 / 2014$ & 240 & 4.22 & 108 \\
\hline IAEA-407 & $2 / 18 / 2014$ & 246 & 3.48 & 111 \\
\hline IAEA-407 & $2 / 18 / 2014$ & 238 & 2.46 & 107 \\
\hline IAEA-407 & $2 / 19 / 2014$ & 236 & 5.31 & 106 \\
\hline IAEA-407 & $2 / 19 / 2014$ & 248 & 6.1 & 112 \\
\hline IAEA-407 & $2 / 19 / 2014$ & 248 & 4.63 & 112 \\
\hline IAEA-407 & $2 / 19 / 2014$ & 247 & 6.02 & 111 \\
\hline IAEA-407 & $2 / 19 / 2014$ & 249 & 6.45 & 112 \\
\hline IAEA-407 & $2 / 19 / 2014$ & 248 & 7.3 & 112 \\
\hline IAEA-407 & $2 / 19 / 2014$ & 244 & 6.57 & 110 \\
\hline IAEA-407 & $2 / 19 / 2014$ & 250 & 6.39 & 113 \\
\hline IAEA-407 & $2 / 19 / 2014$ & 248 & 5.95 & 112 \\
\hline IAEA-407 & $2 / 20 / 2014$ & 237 & 10.5 & 107 \\
\hline IAEA-407 & $2 / 20 / 2014$ & 247 & 7.72 & 111 \\
\hline IAEA-407 & $2 / 20 / 2014$ & 247 & 10.5 & 111 \\
\hline IAEA-407 & $2 / 20 / 2014$ & 254 & 7.02 & 114 \\
\hline IAEA-407 & $2 / 20 / 2014$ & 255 & 11.3 & 115 \\
\hline IAEA-407 & $2 / 21 / 2014$ & 249 & 5.68 & 112 \\
\hline IAEA-407 & $2 / 21 / 2014$ & 242 & 3.91 & 109 \\
\hline IAEA-407 & $2 / 21 / 2014$ & 240 & 4.51 & 108 \\
\hline IAEA-407 & $2 / 21 / 2014$ & 245 & 4.29 & 110 \\
\hline IAEA-407 & $2 / 24 / 2014$ & 238 & 4.73 & 107 \\
\hline IAEA-407 & $2 / 24 / 2014$ & 242 & 4.59 & 109 \\
\hline IAEA-407 & $2 / 24 / 2014$ & 251 & 4.99 & 113 \\
\hline IAEA-407 & $1 / 26 / 2015$ & 231 & 4.21 & 104 \\
\hline IAEA-407 & $1 / 26 / 2015$ & 242 & 4.4 & 109 \\
\hline
\end{tabular}




\begin{tabular}{|c|c|c|c|c|}
\hline $\begin{array}{l}\text { Laboratory } \\
\text { identification }\end{array}$ & Date of analysis & $\begin{array}{c}\text { Mercury, } \\
\text { ng/g dry } \\
\text { weight }\end{array}$ & $\begin{array}{c}\text { Laboratory } \\
\text { detection limit, } \\
\text { ng/g dry } \\
\text { weight }\end{array}$ & $\begin{array}{c}\text { Certified } \\
\text { reference } \\
\text { material } \\
\text { percent } \\
\text { recovery }\end{array}$ \\
\hline IAEA-407 & $1 / 26 / 2015$ & 236 & 4.18 & 106 \\
\hline IAEA-407 & $1 / 26 / 2015$ & 246 & 5.61 & 111 \\
\hline IAEA-407 & $11 / 9 / 2015$ & 214 & 14.3 & 96.5 \\
\hline IAEA-407 & $11 / 9 / 2015$ & 216 & 15.9 & 97.4 \\
\hline IAEA-407 & $11 / 9 / 2015$ & 219 & 17.3 & 98.5 \\
\hline IAEA-407 & $11 / 9 / 2015$ & 223 & 13.1 & 100 \\
\hline IAEA-407 & $11 / 9 / 2015$ & 221 & 14.5 & 99.6 \\
\hline IAEA-407 & $11 / 10 / 2015$ & 218 & 3.83 & 98.4 \\
\hline IAEA-407 & $11 / 10 / 2015$ & 235 & 4.03 & 106 \\
\hline IAEA-407 & $11 / 10 / 2015$ & 230 & 2.89 & 104 \\
\hline IAEA-407 & $11 / 10 / 2015$ & 229 & 3.2 & 103 \\
\hline IAEA-407 & $11 / 10 / 2015$ & 225 & 3.01 & 102 \\
\hline IAEA-407 & $11 / 11 / 2015$ & 213 & 3.61 & 95.8 \\
\hline IAEA-407 & $11 / 11 / 2015$ & 238 & 5.93 & 107 \\
\hline IAEA-407 & $11 / 11 / 2015$ & 229 & 5.11 & 103 \\
\hline IAEA-407 & $11 / 11 / 2015$ & 228 & 4.52 & 103 \\
\hline IAEA-407 & $11 / 11 / 2015$ & 225 & 5.06 & 101 \\
\hline IAEA-407 & $11 / 13 / 2015$ & 215 & 1.33 & 96.9 \\
\hline IAEA-407 & $11 / 13 / 2015$ & 229 & 0.88 & 103 \\
\hline IAEA-407 & $11 / 13 / 2015$ & 232 & 1.1 & 104 \\
\hline IAEA-407 & $11 / 13 / 2015$ & 219 & 1.11 & 98.5 \\
\hline $\begin{array}{l}\text { Laboratory } \\
\text { identification }\end{array}$ & Date of analysis & $\begin{array}{l}\text { Mercury, ng/g } \\
\text { dry weight }\end{array}$ & $\begin{array}{l}\text { Laboratory } \\
\text { detection limit, } \\
\text { ng/g dry } \\
\text { weight }\end{array}$ & $\begin{array}{l}\text { Triplicate } \\
\text { relative } \\
\text { standard } \\
\text { deviation } \\
\text { (percent) }\end{array}$ \\
\hline MSC568T & $2 / 18 / 2014$ & 957 & 4.1 & 1.1 \\
\hline MSC568T & $2 / 18 / 2014$ & 975 & 3.88 & \\
\hline MSC568T & $2 / 18 / 2014$ & 976 & 4.1 & \\
\hline MSC718T & $2 / 18 / 2014$ & 929 & 4.42 & 1.43 \\
\hline MSC718T & $2 / 18 / 2014$ & 956 & 4.04 & \\
\hline MSC718T & $2 / 18 / 2014$ & 948 & 3.83 & \\
\hline MSC299T & $2 / 19 / 2014$ & 714 & 10.1 & 1.2 \\
\hline MSC299T & $2 / 19 / 2014$ & 697 & 8.92 & \\
\hline MSC299T & $2 / 19 / 2014$ & 704 & 6.69 & \\
\hline MSC565T & $2 / 19 / 2014$ & 1,215 & 12.14 & 0.91 \\
\hline MSC565T & $2 / 19 / 2014$ & 1,227 & 12.9 & \\
\hline
\end{tabular}




\begin{tabular}{|c|c|c|c|c|}
\hline $\begin{array}{l}\text { Laboratory } \\
\text { identification }\end{array}$ & Date of analysis & $\begin{array}{l}\text { Mercury, ng/g } \\
\text { dry weight }\end{array}$ & $\begin{array}{c}\text { Laboratory } \\
\text { detection limit, } \\
\text { ng/g dry } \\
\text { weight }\end{array}$ & $\begin{array}{c}\text { Triplicate } \\
\text { relative } \\
\text { standard } \\
\text { deviation } \\
\text { (percent) }\end{array}$ \\
\hline MSC565T & $2 / 19 / 2014$ & 1,237 & 11.38 & \\
\hline MSC887T & $2 / 19 / 2014$ & 328 & 8.35 & 4.39 \\
\hline MSC887T & $2 / 19 / 2014$ & 351 & 7.34 & \\
\hline MSC887T & $2 / 19 / 2014$ & 357 & 13.38 & \\
\hline MSC891T & $2 / 20 / 2014$ & 3,035 & 13.03 & 3.27 \\
\hline MSC891T & $2 / 20 / 2014$ & 3,173 & 15.12 & \\
\hline MSC891T & $2 / 20 / 2014$ & 3,237 & 15.57 & \\
\hline MSC726T & $2 / 21 / 2014$ & 626 & 5.71 & 2.4 \\
\hline MSC726T & $2 / 21 / 2014$ & 656 & 5.15 & \\
\hline MSC726T & $2 / 21 / 2014$ & 648 & 5.78 & \\
\hline MSC730T & $2 / 21 / 2014$ & 982 & 7.45 & 2.08 \\
\hline MSC730T & $2 / 21 / 2014$ & 1,020 & 7.73 & \\
\hline MSC730T & $2 / 21 / 2014$ & 988 & 6.37 & \\
\hline MSC675X & $1 / 26 / 2015$ & 433 & 7.36 & 0.46 \\
\hline MSC675X & $1 / 26 / 2015$ & 435 & 7.5 & \\
\hline MSC675X & $1 / 26 / 2015$ & 431 & 7.5 & \\
\hline MSC147AA & $11 / 9 / 2015$ & 352 & 19.98 & 1.32 \\
\hline MSC147AA & $11 / 9 / 2015$ & 361 & 17.96 & \\
\hline MSC147AA & $11 / 9 / 2015$ & 361 & 20.19 & \\
\hline MSC188AA & $11 / 9 / 2015$ & 462 & 17.79 & 0.88 \\
\hline MSC188AA & $11 / 9 / 2015$ & 460 & 19.36 & \\
\hline MSC188AA & $11 / 9 / 2015$ & 454 & 18.31 & \\
\hline MSC167AA & $11 / 10 / 2015$ & 3,078 & 14.00 & 1.17 \\
\hline MSC167AA & $11 / 10 / 2015$ & 3,010 & 11.09 & \\
\hline MSC167AA & $11 / 10 / 2015$ & 3,024 & 16.11 & \\
\hline MSC196AA & $11 / 10 / 2015$ & 90.3 & 3.71 & 1.89 \\
\hline MSC196AA & $11 / 10 / 2015$ & 86.9 & 3.62 & \\
\hline MSC196AA & $11 / 10 / 2015$ & 88.6 & 4.59 & \\
\hline MSC137AA & $11 / 11 / 2015$ & 1,131 & 18.95 & 4.38 \\
\hline MSC137AA & $11 / 11 / 2015$ & 1,234 & 8.28 & \\
\hline MSC137AA & $11 / 11 / 2015$ & 1,176 & 12.14 & \\
\hline MSC160AA & $11 / 11 / 2015$ & 444 & 5.13 & 1.52 \\
\hline MSC160AA & $11 / 11 / 2015$ & 457 & 6.41 & \\
\hline MSC160AA & $11 / 11 / 2015$ & 447 & 4.74 & \\
\hline MSC186AA & $11 / 13 / 2015$ & 354 & 2.42 & 2.51 \\
\hline MSC186AA & $11 / 13 / 2015$ & 339 & 2.22 & \\
\hline MSC186AA & $11 / 13 / 2015$ & 354 & 2.61 & \\
\hline
\end{tabular}


Table 4. Total mercury concentrations in water from the Boise and Snake Rivers and Brownlee Reservoir and associated field blanks and laboratory matrix spike recovery for samples collected in October and November, 2013-15.

[Site locations are shown in figure 1. Full site names are listed in table 1. Samples collected by City of Boise personnel and analyzed by Boise City Public Works Water Quality Laboratory, Boise, Idaho. Results of matrix spike duplicates are reported as relative percent difference $(\mathrm{RPD})$, where $\{(\mathrm{x} 1-\mathrm{x} 2) /[\mathrm{x} 1+\mathrm{x} 2) / 2] 100$, and $\mathrm{x}=$ sample concentration. Abbreviations: $<$, less than; ng/L, nanograms per liter; $\mu \mathrm{g} / \mathrm{L}$, micrograms per liter]

\begin{tabular}{lllccc}
\hline $\begin{array}{c}\text { USGS site } \\
\text { identification }\end{array}$ & Site name & Sample date & Sample time & $\begin{array}{c}\text { Total mercury } \\
\text { concentration } \\
\text { (ng/L) }\end{array}$ & $\begin{array}{c}\text { Trip blank } \\
\text { concentration } \\
\text { (ng/L) }\end{array}$ \\
\hline 13203760 & Eckert & $11 / 1 / 2013$ & 0937 & 0.73 & 0.22 \\
13210050 & Middleton & $11 / 1 / 2013$ & 1057 & 0.89 & $<0.20$ \\
13213030 & Boise mouth & $11 / 1 / 2013$ & 1221 & 1.2 & 0.70 \\
13172500 & Murphy & $10 / 28 / 2013$ & 1515 & 0.93 & $<0.20$ \\
13213100 & Nyssa & $10 / 28 / 2013$ & 1323 & 1.2 & $<0.20$ \\
4422221171355 & Brownlee & $10 / 28 / 2013$ & 1138 & 8.8 & $<0.20$ \\
13210050 & Middleton & $10 / 23 / 2014$ & 1055 & 1.2 & $<0.20$ \\
13203760 & Eckert & $10 / 7 / 2015$ & 0945 & 0.77 & - \\
13210050 & Middleton & $10 / 7 / 2015$ & 1047 & 1.1 & - \\
13213030 & Boise mouth & $10 / 7 / 2015$ & 1131 & 1.6 & $<0.20$ \\
13172500 & Murphy & $10 / 12 / 2015$ & 1455 & 0.48 & $<0.20$ \\
13213100 & Nyssa & $10 / 12 / 2015$ & 1329 & 0.61 & -- \\
4422221171355 & Brownlee & $10 / 12 / 2015$ & 1155 & 0.71 & - \\
\hline
\end{tabular}

Boise City Public Works Water Quality Laboratory matrix spike recovery

\begin{tabular}{lllcc}
\hline Lab sample ID & Date of analysis & $\begin{array}{c}\text { Total mercury spike } \\
\text { concentration }(\mu \mathrm{g} / \mathrm{L})\end{array}$ & $\begin{array}{c}\text { Laboratory } \\
\text { matrix spike, } \\
\text { percent recovery }\end{array}$ & $\begin{array}{c}\text { Matrix spike } \\
\text { duplicates, RPD }\end{array}$ \\
\hline AP07402 & $11 / 12 / 2013$ & 0.00019 & 100 & 2.0 \\
AP07406 & $11 / 12 / 2013$ & 0.00019 & 96.5 & 5.9 \\
AQ07919 & $10 / 30 / 2014$ & 0.00022 & 94.8 & 8.1 \\
B5J0813 & $10 / 8 / 2015$ & 0.005 & 96.5 & 3.5 \\
B5J1214 & $10 / 12 / 2015$ & 0.005 & 94.9 & 0.41 \\
\hline
\end{tabular}

${ }^{\mathrm{a}}$ Environmental Protection Agency total mercury chronic aquatic life criteria for Idaho is $12 \mathrm{ng} / \mathrm{L}$

(Idaho Department of Environmental Quality, variously dated). 
Table 5. Individual sport fish tissue total mercury concentrations, fish size data, and statistical site summaries in samples collected from the Boise and Snake Rivers and Brownlee Reservoir, Idaho and Oregon, October 2013-15.

[Site locations are shown in figure 1. Abbreviations: $\mathrm{g}$, gram; mm, millimeter; $\mathrm{mg} / \mathrm{kg}$, milligram per kilogram]

\begin{tabular}{|c|c|c|c|c|c|c|c|c|c|c|c|}
\hline Site name & Sample date & Time & $\begin{array}{c}\text { Total } \\
\text { length } \\
(\mathrm{mm})\end{array}$ & $\begin{array}{l}\text { Weight } \\
\text { (g) }\end{array}$ & $\begin{array}{l}\text { Mercury, } \\
\text { dry } \\
\text { weight } \\
(\mathrm{mg} / \mathrm{kg})\end{array}$ & $\begin{array}{l}\text { Percent } \\
\text { water }\end{array}$ & $\begin{array}{l}\text { Percent } \\
\text { solids }\end{array}$ & $\begin{array}{l}\text { Mercury } \\
\text { wet weight, } \\
(\mathrm{mg} / \mathrm{kg})\end{array}$ & $\begin{array}{l}\text { Mercury wet } \\
\text { weight } \\
\text { geometric } \\
\text { mean per } \\
\text { site }(\mathrm{mg} / \mathrm{kg})\end{array}$ & $\begin{array}{c}\text { Mercury, } \\
\text { wet weight } \\
\text { median per } \\
\text { site } \\
(\mathrm{mg} / \mathrm{kg})\end{array}$ & $\begin{array}{c}\text { Mercury } \\
\text { wet weight } \\
\text { average } \\
\text { per site } \\
\text { (mg/kg) }\end{array}$ \\
\hline \multicolumn{12}{|c|}{ Mountain Whitefish } \\
\hline Boise River at Eckert & $10 / 29 / 2013$ & 1001 & 440 & 959 & 0.975 & 74.8 & 25.2 & 0.25 & 0.18 & 0.18 & 0.19 \\
\hline \multirow[t]{9}{*}{ Road, near Boise, Idaho } & & 1002 & 420 & 626 & 1.19 & 76.4 & 23.6 & 0.28 & & & \\
\hline & & 1003 & 450 & 850 & 0.94 & 76.2 & 23.8 & 0.22 & & & \\
\hline & & 1004 & 400 & 702 & 0.507 & 70.1 & 29.9 & 0.15 & & & \\
\hline & & 1005 & 425 & 699 & 0.851 & 70.6 & 29.4 & 0.25 & & & \\
\hline & & 1006 & 435 & 866 & 0.626 & 67.7 & 32.3 & 0.20 & & & \\
\hline & & 1007 & 410 & 636 & 0.58 & 75.7 & 24.3 & 0.14 & & & \\
\hline & & 1008 & 320 & 360 & 0.436 & 74.6 & 25.4 & 0.11 & & & \\
\hline & & 1009 & 310 & 330 & 0.418 & 71.6 & 28.4 & 0.12 & & & \\
\hline & & 1010 & 320 & 315 & 0.498 & 73.8 & 26.2 & 0.13 & & & \\
\hline \multicolumn{12}{|c|}{ Rainbow Trout } \\
\hline Boise River at Eckert & $10 / 5 / 2015$ & 931 & 390 & 238 & 0.088 & 77.3 & 22.7 & 0.02 & 0.02 & 0.02 & 0.02 \\
\hline \multirow[t]{9}{*}{ Road, near Boise, Idaho } & & 932 & 280 & 261 & 0.124 & 78.1 & 21.9 & 0.03 & & & \\
\hline & & 933 & 250 & 147 & 0.15 & 79.8 & 20.2 & 0.03 & & & \\
\hline & & 934 & 270 & 184 & 0.113 & 79.3 & 20.7 & 0.02 & & & \\
\hline & & 935 & 295 & 255 & 0.112 & 79.1 & 20.9 & 0.02 & & & \\
\hline & & 936 & 290 & 234 & 0.089 & 78.6 & 21.4 & 0.02 & & & \\
\hline & & 937 & 280 & 236 & 0.089 & 78.0 & 22.0 & 0.02 & & & \\
\hline & & 938 & 275 & 190 & 0.1 & 80.2 & 19.8 & 0.02 & & & \\
\hline & & 939 & 295 & 235 & 0.094 & 79.1 & 20.9 & 0.02 & & & \\
\hline & & 940 & 280 & 225 & 0.1 & 78.8 & 21.2 & 0.02 & & & \\
\hline
\end{tabular}




\begin{tabular}{|c|c|c|c|c|c|c|c|c|c|c|c|}
\hline Site name & Sample date & Time & $\begin{array}{l}\text { Total } \\
\text { length } \\
(\mathrm{mm})\end{array}$ & $\begin{array}{l}\text { Weight } \\
\text { (g) }\end{array}$ & $\begin{array}{c}\text { Mercury, } \\
\text { dry } \\
\text { weight } \\
(\mathrm{mg} / \mathrm{kg})\end{array}$ & $\begin{array}{c}\text { Percent } \\
\text { water }\end{array}$ & $\begin{array}{l}\text { Percent } \\
\text { solids }\end{array}$ & $\begin{array}{l}\text { Mercury } \\
\text { wet weight, } \\
(\mathrm{mg} / \mathrm{kg})\end{array}$ & $\begin{array}{l}\text { Mercury wet } \\
\text { weight } \\
\text { geometric } \\
\text { mean per } \\
\text { site }(\mathrm{mg} / \mathrm{kg})\end{array}$ & $\begin{array}{c}\text { Mercury, } \\
\text { wet weight } \\
\text { median per } \\
\text { site } \\
(\mathrm{mg} / \mathrm{kg})\end{array}$ & $\begin{array}{c}\text { Mercury } \\
\text { wet weight } \\
\text { average } \\
\text { per site } \\
\text { (mg/kg) }\end{array}$ \\
\hline \multicolumn{12}{|c|}{ Mountain Whitefish } \\
\hline Boise River near & $10 / 21 / 2013$ & 1201 & 380 & 491 & 0.527 & 74.0 & 26.0 & 0.14 & 0.17 & 0.17 & 0.17 \\
\hline \multirow[t]{26}{*}{ Middleton, Idaho } & & 1202 & 280 & 182 & 1.08 & 74.1 & 25.9 & 0.28 & & & \\
\hline & & 1203 & 395 & 506 & 0.652 & 74.0 & 26.0 & 0.17 & & & \\
\hline & & 1204 & 295 & 217 & 0.948 & 77.8 & 22.2 & 0.21 & & & \\
\hline & & 1205 & 315 & 321 & 0.708 & 75.8 & 24.2 & 0.17 & & & \\
\hline & & 1206 & 280 & 207 & 0.783 & 78.1 & 21.9 & 0.17 & & & \\
\hline & & 1207 & 280 & 186 & 0.534 & 74.9 & 25.1 & 0.13 & & & \\
\hline & & 1208 & 295 & 211 & 0.625 & 76.8 & 23.2 & 0.15 & & & \\
\hline & & 1209 & 275 & 190 & 0.906 & 76.7 & 23.3 & 0.21 & & & \\
\hline & & 1210 & 260 & 149 & 0.433 & 73.3 & 26.7 & 0.12 & & & \\
\hline & $10 / 23 / 2014$ & 1131 & 330 & 340 & 0.432 & 74.8 & 25.2 & 0.11 & 0.17 & 0.18 & 0.17 \\
\hline & & 1132 & 135 & 250 & 0.76 & 74.5 & 25.5 & 0.19 & & & \\
\hline & & 1133 & 310 & 279 & 0.684 & 71.5 & 28.5 & 0.19 & & & \\
\hline & & 1134 & 300 & 257 & 0.768 & 74.5 & 25.5 & 0.20 & & & \\
\hline & & 1135 & 270 & 180 & 0.49 & 73.0 & 27.0 & 0.13 & & & \\
\hline & & 1136 & 270 & 179 & 0.943 & 75.3 & 24.7 & 0.23 & & & \\
\hline & & 1137 & 330 & 382 & 0.694 & 74.2 & 25.8 & 0.18 & & & \\
\hline & & 1138 & 135 & 259 & 0.589 & 74.9 & 25.1 & 0.15 & & & \\
\hline & & 1139 & 235 & 300 & 0.659 & 73.0 & 27.0 & 0.18 & & & \\
\hline & & 1140 & 310 & 259 & 0.6 & 72.4 & 27.6 & 0.17 & & & \\
\hline & $10 / 5 / 2015$ & 1301 & 300 & 296 & 0.691 & 76.7 & 23.3 & 0.16 & 0.11 & 0.11 & 0.11 \\
\hline & & 1302 & 315 & 308 & 0.709 & 75.3 & 24.7 & 0.18 & & & \\
\hline & & 1303 & 280 & 205 & 0.318 & 76.1 & 23.9 & 0.08 & & & \\
\hline & & 1304 & 275 & 215 & 0.456 & 76.6 & 23.4 & 0.11 & & & \\
\hline & & 1305 & 290 & 247 & 0.45 & 75.9 & 24.1 & 0.11 & & & \\
\hline & & 1306 & 290 & 221 & 0.438 & 77.6 & 22.4 & 0.10 & & & \\
\hline & & 1307 & 305 & 286 & 0.219 & 77.8 & 22.2 & 0.05 & & & \\
\hline
\end{tabular}




\begin{tabular}{|c|c|c|c|c|c|c|c|c|c|c|c|}
\hline Site name & Sample date & Time & $\begin{array}{l}\text { Total } \\
\text { length } \\
(\mathrm{mm})\end{array}$ & $\begin{array}{l}\text { Weight } \\
\text { (g) }\end{array}$ & $\begin{array}{c}\text { Mercury, } \\
\text { dry } \\
\text { weight } \\
(\mathrm{mg} / \mathrm{kg})\end{array}$ & $\begin{array}{l}\text { Percent } \\
\text { water }\end{array}$ & $\begin{array}{l}\text { Percent } \\
\text { solids }\end{array}$ & $\begin{array}{l}\text { Mercury } \\
\text { wet weight, } \\
(\mathrm{mg} / \mathrm{kg})\end{array}$ & $\begin{array}{l}\text { Mercury wet } \\
\text { weight } \\
\text { geometric } \\
\text { mean per } \\
\text { site }(\mathrm{mg} / \mathrm{kg})\end{array}$ & $\begin{array}{c}\text { Mercury, } \\
\text { wet weight } \\
\text { median per } \\
\text { site } \\
(\mathrm{mg} / \mathrm{kg})\end{array}$ & $\begin{array}{c}\text { Mercury } \\
\text { wet weight } \\
\text { average } \\
\text { per site } \\
\text { (mg/kg) }\end{array}$ \\
\hline & & 1308 & 280 & 231 & 0.572 & 76.9 & 23.1 & 0.13 & & & \\
\hline & & 1309 & 350 & 405 & 0.41 & 75.2 & 24.8 & 0.10 & & & \\
\hline & & 1310 & 280 & 215 & 0.447 & 74.5 & 25.5 & 0.11 & & & \\
\hline \multicolumn{12}{|c|}{ Channel Catfish } \\
\hline \multirow{16}{*}{$\begin{array}{l}\text { Boise River at mouth, } \\
\text { near Parma, Idaho }\end{array}$} & $10 / 21 / 2013$ & 1501 & 665 & 3,485 & 1.58 & 81.2 & 18.8 & 0.30 & 0.28 & 0.28 & 0.33 \\
\hline & & 1502 & 580 & 2,086 & 0.35 & 74.3 & 25.7 & 0.09 & & & \\
\hline & & 1503 & 570 & 1,595 & 2.23 & 80.6 & 19.4 & 0.43 & & & \\
\hline & & 1504 & 550 & 1,211 & 3.17 & 79.9 & 20.1 & 0.64 & & & \\
\hline & & 1505 & 665 & 3,080 & 1.08 & 80.7 & 19.3 & 0.21 & & & \\
\hline & & 1506 & 592 & 2,245 & 2.33 & 78.0 & 22.0 & 0.51 & & & \\
\hline & & 1507 & 578 & 2,017 & 1.25 & 79.2 & 20.8 & 0.26 & & & \\
\hline & & 1508 & 569 & 2,007 & 1.02 & 79.7 & 20.3 & 0.21 & & & \\
\hline & & 1509 & 575 & 1,785 & 2.29 & 79.6 & 20.4 & 0.47 & & & \\
\hline & & 1510 & 597 & 2,326 & 0.644 & 78.4 & 21.6 & 0.14 & & & \\
\hline & $10 / 7 / 2015$ & 1101 & 650 & 3,000 & 1.18 & 79.0 & 21.0 & 0.25 & 0.22 & 0.24 & 0.23 \\
\hline & & 1102 & 680 & 4,100 & 1.36 & 80.5 & 19.5 & 0.27 & & & \\
\hline & & 1103 & 550 & 2,800 & 1.22 & 81.4 & 18.6 & 0.23 & & & \\
\hline & & 1104 & 650 & 3,800 & 0.729 & 80.7 & 19.3 & 0.14 & & & \\
\hline & & 1105 & 660 & 2,500 & 1.32 & 79.9 & 20.1 & 0.27 & & & \\
\hline & & 1106 & 560 & 2,000 & 0.939 & 79.6 & 20.4 & 0.19 & & & \\
\hline \multicolumn{12}{|c|}{ Smallmouth Bass } \\
\hline Snake River near & $10 / 22 / 2013$ & 1001 & 330 & 557 & 0.517 & 77.6 & 22.4 & 0.12 & 0.16 & 0.17 & 0.17 \\
\hline \multirow[t]{6}{*}{ Murphy, Idaho } & & 1002 & 388 & 906 & 1.28 & 78.2 & 21.8 & 0.28 & & & \\
\hline & & 1003 & 305 & 442 & 0.64 & 77.9 & 22.1 & 0.14 & & & \\
\hline & & 1004 & 410 & 1,108 & 0.659 & 77.3 & 22.7 & 0.15 & & & \\
\hline & & 1005 & 342 & 661 & 0.918 & 76.6 & 23.4 & 0.21 & & & \\
\hline & & 1006 & 323 & 441 & 0.219 & 76.7 & 23.3 & 0.05 & & & \\
\hline & & 1007 & 360 & 689 & 1.03 & 77.9 & 22.1 & 0.23 & & & \\
\hline
\end{tabular}




\begin{tabular}{|c|c|c|c|c|c|c|c|c|c|c|c|}
\hline Site name & Sample date & Time & $\begin{array}{c}\text { Total } \\
\text { length } \\
(\mathrm{mm})\end{array}$ & $\begin{array}{l}\text { Weight } \\
\text { (g) }\end{array}$ & $\begin{array}{c}\text { Mercury, } \\
\text { dry } \\
\text { weight } \\
(\mathrm{mg} / \mathrm{kg})\end{array}$ & $\begin{array}{c}\text { Percent } \\
\text { water }\end{array}$ & $\begin{array}{l}\text { Percent } \\
\text { solids }\end{array}$ & $\begin{array}{l}\text { Mercury } \\
\text { wet weight, } \\
(\mathrm{mg} / \mathrm{kg})\end{array}$ & $\begin{array}{l}\text { Mercury wet } \\
\text { weight } \\
\text { geometric } \\
\text { mean per } \\
\text { site }(\mathrm{mg} / \mathrm{kg})\end{array}$ & $\begin{array}{c}\text { Mercury, } \\
\text { wet weight } \\
\text { median per } \\
\text { site } \\
(\mathrm{mg} / \mathrm{kg})\end{array}$ & $\begin{array}{c}\text { Mercury } \\
\text { wet weight } \\
\text { average } \\
\text { per site } \\
\text { (mg/kg) }\end{array}$ \\
\hline & & 1008 & 329 & 596 & 0.953 & 77.7 & 22.3 & 0.21 & & & \\
\hline & & 1009 & 335 & 535 & 0.788 & 77.5 & 22.5 & 0.18 & & & \\
\hline & & 1010 & 317 & 457 & 0.696 & 77.3 & 22.7 & 0.16 & & & \\
\hline & $10 / 8 / 2015$ & 1201 & 370 & 682 & 1.57 & 78.9 & 21.1 & 0.33 & 0.15 & 0.16 & 0.16 \\
\hline & & 1202 & 345 & 693 & 0.775 & 78.3 & 21.7 & 0.17 & & & \\
\hline & & 1203 & 340 & 581 & 0.772 & 78.2 & 21.8 & 0.17 & & & \\
\hline & & 1204 & 335 & 504 & 0.758 & 79.7 & 20.3 & 0.15 & & & \\
\hline & & 1205 & 310 & 475 & 0.36 & 78.4 & 21.6 & 0.08 & & & \\
\hline & & 1206 & 350 & 612 & 0.925 & 79.6 & 20.4 & 0.19 & & & \\
\hline & & 1207 & 305 & 339 & 0.664 & 78.7 & 21.3 & 0.14 & & & \\
\hline & & 1208 & 310 & 412 & 0.623 & 78.9 & 21.1 & 0.13 & & & \\
\hline & & 1209 & 315 & 381 & 1.04 & 79.2 & 20.8 & 0.22 & & & \\
\hline & & 1210 & 300 & 334 & 0.302 & 79.1 & 20.9 & 0.06 & & & \\
\hline \multicolumn{12}{|c|}{ Channel Catfish } \\
\hline Snake River near & $10 / 22 / 2013$ & 1201 & 540 & 1,747 & 0.889 & 79.8 & 20.2 & 0.18 & 0.18 & 0.18 & 0.21 \\
\hline \multirow[t]{13}{*}{ Murphy, Idaho } & & 1202 & 578 & 1,841 & 0.898 & 79.1 & 20.9 & 0.19 & & & \\
\hline & & 1203 & 670 & 2,663 & 0.568 & 78.8 & 21.2 & 0.12 & & & \\
\hline & & 1204 & 648 & 2,526 & 2.7 & 81.0 & 19.0 & 0.51 & & & \\
\hline & & 1205 & 708 & 3,880 & 0.648 & 78.1 & 21.9 & 0.14 & & & \\
\hline & & 1206 & 560 & 1,717 & 0.536 & 78.6 & 21.4 & 0.11 & & & \\
\hline & & 1207 & 685 & 3,526 & 1.65 & 79.8 & 20.2 & 0.33 & & & \\
\hline & & 1208 & 640 & 2,715 & 0.446 & 79.0 & 21.0 & 0.09 & & & \\
\hline & & 1209 & 605 & 2,496 & 0.988 & 79.1 & 20.9 & 0.21 & & & \\
\hline & & 1210 & 680 & 3,017 & 0.853 & 79.4 & 20.6 & 0.18 & & & \\
\hline & $10 / 8 / 2015$ & 1101 & 630 & 2,802 & 2.68 & 79.8 & 20.2 & 0.54 & 0.13 & 0.11 & 0.16 \\
\hline & & 1102 & 590 & 2,410 & 0.46 & 77.8 & 22.2 & 0.10 & & & \\
\hline & & 1103 & 605 & 2,715 & 0.391 & 78.7 & 21.3 & 0.08 & & & \\
\hline & & 1104 & 590 & 2,614 & 0.354 & 77.4 & 22.6 & 0.08 & & & \\
\hline
\end{tabular}




\begin{tabular}{|c|c|c|c|c|c|c|c|c|c|c|c|}
\hline Site name & Sample date & Time & $\begin{array}{l}\text { Total } \\
\text { length } \\
(\mathrm{mm})\end{array}$ & $\begin{array}{l}\text { Weight } \\
\text { (g) }\end{array}$ & $\begin{array}{c}\text { Mercury, } \\
\text { dry } \\
\text { weight } \\
(\mathrm{mg} / \mathrm{kg})\end{array}$ & $\begin{array}{c}\text { Percent } \\
\text { water }\end{array}$ & $\begin{array}{l}\text { Percent } \\
\text { solids }\end{array}$ & $\begin{array}{l}\text { Mercury } \\
\text { wet weight, } \\
(\mathrm{mg} / \mathrm{kg})\end{array}$ & $\begin{array}{l}\text { Mercury wet } \\
\text { weight } \\
\text { geometric } \\
\text { mean per } \\
\text { site }(\mathrm{mg} / \mathrm{kg})\end{array}$ & $\begin{array}{c}\text { Mercury, } \\
\text { wet weight } \\
\text { median per } \\
\text { site } \\
(\mathrm{mg} / \mathrm{kg})\end{array}$ & $\begin{array}{c}\text { Mercury } \\
\text { wet weight } \\
\text { average } \\
\text { per site } \\
\text { (mg/kg) }\end{array}$ \\
\hline & & 1105 & 580 & 1,932 & 0.516 & 78.5 & 21.5 & 0.11 & & & \\
\hline & & 1106 & 635 & 2,996 & 0.505 & 77.6 & 22.4 & 0.11 & & & \\
\hline & & 1107 & 720 & 4,902 & 0.651 & 78.5 & 21.5 & 0.14 & & & \\
\hline & & 1108 & 715 & 4,341 & 1.24 & 80.1 & 19.9 & 0.25 & & & \\
\hline & & 1109 & 660 & 3,367 & 0.606 & 78.5 & 21.5 & 0.13 & & & \\
\hline & & 1110 & 525 & 1,624 & 0.409 & 78.5 & 21.5 & 0.09 & & & \\
\hline \multicolumn{12}{|c|}{ Channel Catfish } \\
\hline Snake River at & $10 / 22 / 2013$ & 1331 & 535 & 1,409 & 0.33 & 73.4 & 26.6 & 0.09 & 0.13 & 0.14 & 0.14 \\
\hline \multirow[t]{19}{*}{ Nyssa, Oregon } & & 1332 & 523 & 1,299 & 0.528 & 75.1 & 24.9 & 0.13 & & & \\
\hline & & 1333 & 510 & 1,202 & 0.704 & 76.5 & 23.5 & 0.17 & & & \\
\hline & & 1334 & 610 & 2,187 & 0.822 & 82.5 & 17.5 & 0.14 & & & \\
\hline & & 1335 & 697 & 2,122 & 0.524 & 78.0 & 22.0 & 0.12 & & & \\
\hline & & 1336 & 605 & 2,228 & 0.247 & 75.0 & 25.0 & 0.06 & & & \\
\hline & & 1337 & 620 & 2,159 & 1.27 & 83.0 & 17.0 & 0.22 & & & \\
\hline & & 1338 & 610 & 2,368 & 0.368 & 72.9 & 27.1 & 0.10 & & & \\
\hline & & 1339 & 648 & 2,399 & 0.821 & 80.7 & 19.3 & 0.16 & & & \\
\hline & & 1340 & 630 & 2,404 & 1.23 & 80.3 & 19.7 & 0.24 & & & \\
\hline & $10 / 1 / 2015$ & 901 & 545 & 1,780 & 0.525 & 74.2 & 25.8 & 0.14 & 0.13 & 0.13 & 0.13 \\
\hline & & 902 & 619 & 3,201 & 0.592 & 80.0 & 20.0 & 0.12 & & & \\
\hline & & 903 & 591 & 2,115 & 0.822 & 80.7 & 19.3 & 0.16 & & & \\
\hline & & 904 & 483 & 1,427 & 0.618 & 78.6 & 21.4 & 0.13 & & & \\
\hline & & 905 & 585 & 2,308 & 0.443 & 78.3 & 21.7 & 0.10 & & & \\
\hline & & 906 & 595 & 2,493 & 0.555 & 79.5 & 20.5 & 0.11 & & & \\
\hline & & 907 & 585 & 2,367 & 0.632 & 78.1 & 21.9 & 0.14 & & & \\
\hline & & 908 & 640 & 2,808 & 0.46 & 79.4 & 20.6 & 0.10 & & & \\
\hline & & 909 & 640 & 3,097 & 0.67 & 78.4 & 21.6 & 0.15 & & & \\
\hline & & 910 & 620 & 1,437 & 0.623 & 80.7 & 19.3 & 0.12 & & & \\
\hline
\end{tabular}




\begin{tabular}{|c|c|c|c|c|c|c|c|c|c|c|c|}
\hline Site name & Sample date & Time & $\begin{array}{l}\text { Total } \\
\text { length } \\
(\mathrm{mm})\end{array}$ & $\begin{array}{l}\text { Weight } \\
\text { (g) }\end{array}$ & $\begin{array}{l}\text { Mercury, } \\
\text { dry } \\
\text { weight } \\
(\mathrm{mg} / \mathrm{kg})\end{array}$ & $\begin{array}{c}\text { Percent } \\
\text { water }\end{array}$ & $\begin{array}{l}\text { Percent } \\
\text { solids }\end{array}$ & $\begin{array}{c}\text { Mercury } \\
\text { wet weight, } \\
(\mathrm{mg} / \mathrm{kg})\end{array}$ & $\begin{array}{l}\text { Mercury wet } \\
\text { weight } \\
\text { geometric } \\
\text { mean per } \\
\text { site }(\mathrm{mg} / \mathrm{kg})\end{array}$ & $\begin{array}{c}\text { Mercury, } \\
\text { wet weight } \\
\text { median per } \\
\text { site } \\
(\mathrm{mg} / \mathrm{kg})\end{array}$ & $\begin{array}{c}\text { Mercury } \\
\text { wet weight } \\
\text { average } \\
\text { per site } \\
\text { (mg/kg) }\end{array}$ \\
\hline \multicolumn{12}{|c|}{ Smallmouth Bass } \\
\hline Brownlee Reservior & $10 / 23 / 2013$ & 1401 & 452 & 1,306 & 2.05 & 77.9 & 22.1 & 0.45 & 0.32 & 0.32 & 0.32 \\
\hline \multirow[t]{9}{*}{ At Burnt River, Oregon } & & 1402 & 355 & 647 & 1.28 & 77.6 & 22.4 & 0.29 & & & \\
\hline & & 1403 & 451 & 1,378 & 1.52 & 77.9 & 22.1 & 0.34 & & & \\
\hline & & 1404 & 344 & 620 & 1.17 & 77.3 & 22.7 & 0.27 & & & \\
\hline & & 1405 & 380 & 888 & 1.75 & 78.5 & 21.5 & 0.38 & & & \\
\hline & & 1406 & 330 & 456 & 1.13 & 78.2 & 21.8 & 0.25 & & & \\
\hline & & 1407 & 305 & 424 & 1.18 & 77.8 & 22.2 & 0.26 & & & \\
\hline & & 1408 & 377 & 789 & 1.64 & 78.2 & 21.8 & 0.36 & & & \\
\hline & & 1409 & 351 & 737 & 1.3 & 76.9 & 23.1 & 0.30 & & & \\
\hline & & 1410 & 356 & 673 & 1.52 & 77.7 & 22.3 & 0.34 & & & \\
\hline \multicolumn{12}{|c|}{ Channel Catfish } \\
\hline Brownlee Reservior & $10 / 7 / 2015$ & 1201 & 623 & 2,102 & 1.68 & 79.8 & 20.2 & 0.34 & 0.18 & 0.16 & 0.22 \\
\hline \multirow[t]{9}{*}{ At Burnt River, Oregon } & & 1202 & 631 & 3,418 & 0.844 & 80.3 & 19.7 & 0.17 & & & \\
\hline & & 1203 & 650 & 3,750 & 0.599 & 78.8 & 21.2 & 0.13 & & & \\
\hline & & 1204 & 664 & 3,675 & 1.92 & 80.8 & 19.2 & 0.37 & & & \\
\hline & & 1205 & 614 & 2,896 & 0.56 & 78.1 & 21.9 & 0.12 & & & \\
\hline & & 1206 & 642 & 2,950 & 3.02 & 80.7 & 19.3 & 0.58 & & & \\
\hline & & 1207 & 625 & 2,850 & 0.384 & 78.8 & 21.2 & 0.08 & & & \\
\hline & & 1208 & 659 & 3,648 & 0.378 & 77.4 & 22.6 & 0.09 & & & \\
\hline & & 1209 & 691 & 3,941 & 0.736 & 78.6 & 21.4 & 0.16 & & & \\
\hline & & 1210 & 571 & 2,171 & 0.724 & 79.9 & 20.1 & 0.15 & & & \\
\hline
\end{tabular}


Table 6. Selenium concentrations in individual sport fish tissue collected from the Boise and Snake Rivers and Brownlee Reservoir, Idaho and Oregon, October 2013-15.

[Site locations are shown in figure 1. Full site names are listed in table 1. Abbreviations: $\mu \mathrm{mol} / \mathrm{kg}$, micromoles per kilogram; $\mathrm{mg} / \mathrm{kg}$, milligram per kilogram; dry wt, dry weight; wet wt, wet weight]

\begin{tabular}{|c|c|c|c|c|c|c|c|c|c|c|c|}
\hline Site & $\begin{array}{l}\text { USGS site } \\
\text { identification }\end{array}$ & Sample date & Species & $\begin{array}{l}\text { Number in } \\
\text { composite }\end{array}$ & $\begin{array}{l}\text { Selenium } \\
\text { (mg/kg, dry } \\
\text { wt) }\end{array}$ & $\begin{array}{l}\text { Percent } \\
\text { water }\end{array}$ & $\begin{array}{l}\text { Percent } \\
\text { solids }\end{array}$ & $\begin{array}{c}\text { Selenium } \\
\text { (mg/kg, wet } \\
\text { wt) }\end{array}$ & $\begin{array}{c}\text { Selenium } \\
\text { ( } \mu \mathrm{mol} / \mathrm{kg} \text {, } \\
\text { wet wt.) }\end{array}$ & $\begin{array}{c}\text { Mercury } \\
\text { ( } \mu \mathrm{mol} / \mathrm{kg}, \\
\text { wet wt., } \\
\text { average) }\end{array}$ & $\begin{array}{l}\text { Molar } \\
\text { Ratio, } \\
\text { Se/Hg }\end{array}$ \\
\hline Eckert & 13203760 & $10 / 29 / 2013$ & mountain whitefish & 10 & 0.30 & 75.4 & 24.6 & 0.07 & 0.89 & 0.95 & 0.94 \\
\hline Middleton & 13210050 & $10 / 21 / 2013$ & mountain whitefish & 10 & 0.77 & 78.8 & 21.2 & 0.16 & 2.03 & 0.85 & 2.4 \\
\hline Boise mouth & 13213030 & $10 / 30 / 2013$ & channel catfish & 10 & 0.72 & 80.6 & 19.4 & 0.14 & 1.77 & 1.65 & 1.1 \\
\hline Murphy & 13172500 & $10 / 22 / 2013$ & channel catfish & 10 & 0.67 & 78.4 & 21.6 & 0.14 & 1.77 & 1.05 & 1.7 \\
\hline Murphy & 13172500 & $10 / 22 / 2013$ & smallmouth bass & 10 & 2.13 & 77.1 & 22.9 & 0.49 & 6.20 & 0.85 & 7.3 \\
\hline Nyssa & 13213100 & $10 / 22 / 2013$ & channel catfish & 10 & 0.88 & 79.8 & 20.2 & 0.18 & 2.28 & 0.70 & 3.3 \\
\hline Brownlee & 4422221171355 & $10 / 23 / 2013$ & smallmouth bass & 10 & 1.48 & 78.4 & 21.6 & 0.32 & 4.05 & 1.60 & 2.5 \\
\hline Middleton & 13210050 & $10 / 23 / 2014$ & mountain whitefish & 10 & 1.07 & 76.4 & 23.6 & 0.25 & 3.17 & 0.85 & 3.7 \\
\hline Eckert & 13203760 & $10 / 5 / 2015$ & rainbow trout & 10 & 0.84 & 76.9 & 23.1 & 0.19 & 2.41 & 0.10 & 24.1 \\
\hline Middleton & 13210050 & $10 / 5 / 2015$ & mountain whitefish & 10 & 0.52 & 71.6 & 28.4 & 0.15 & 1.90 & 0.55 & 3.5 \\
\hline Boise mouth & 13213030 & $10 / 7 / 2015$ & channel catfish & 6 & 0.93 & 76.3 & 23.7 & 0.22 & 2.79 & 1.65 & 1.7 \\
\hline Murphy & 13172500 & $10 / 8 / 2015$ & channel catfish & 10 & 0.87 & 75.3 & 24.7 & 0.21 & 2.66 & 0.80 & 3.3 \\
\hline Murphy & 13172500 & $10 / 8 / 2015$ & smallmouth bass & 10 & 1.74 & 76.8 & 23.2 & 0.40 & 5.06 & 0.80 & 6.3 \\
\hline Nyssa & 13213100 & $10 / 1 / 2015$ & channel catfish & 10 & 0.83 & 77.6 & 22.4 & 0.19 & 2.41 & 0.65 & 3.7 \\
\hline Brownlee & 4422221171355 & $10 / 7 / 2015$ & channel catfish & 10 & 0.57 & 78.7 & 21.3 & 0.12 & 1.52 & 1.10 & 1.4 \\
\hline
\end{tabular}



Publishing support provided by the U.S. Geological Survey Science Publishing Network, Tacoma Publishing Service Center

For more information concerning the research in this report, contact the Director, Idaho Water Science Center

U.S. Geological Survey

230 Collins Road

Boise, Idaho 83702

http://id.water.usgs.gov 
